\title{
Biochemical, histological and histochemical studies of oat (Avena sativa) on hyperlipidemic rats.
}

\author{
Eman G.E. Helal* , Fatma Eid** and Amira M. Salah EL-Din* \\ Zoology Department(*physiology,**histology), Faculty of Science, Al- \\ Azhar University
}

\begin{abstract}
Hyperlipidemia : is an elevation of lipids in the blood stream and these lipids include: fats, fatty acids, cholesterol, cholesterol esters, phospholipids, and triglycerides. Hyperlipidemia is associated with hepatic fat accumulation .

Material and methods:

Six groups (5rat/group) of female albino (Rattus albinus) were used. The $1^{\text {st }}$ group used as control, in the $2^{\text {nd }}$ group hyperlipidemia ( $25 \%$ fat $\& 2 \%$ cholesterol) was induced for 3 weeks only then sacrified, the $3^{\text {rd }}$ group was hyperlipidemic rats for 3 weeks then left other 3 weeks without any additional treatment as a recovery period, the $4^{\text {th }}$ group served as hyperlipidemic group for 3 weeks then treated with Avena sativa for another 3 weeks ( $200 \mathrm{~g} / \mathrm{Kg}$ diet ), the $5^{\text {th }}$ group was hyperlipidemic ( $25 \%$ fat $\& 2 \%$ cholesterol) for 6 weeks and the $6^{\text {th }}$ group served as hyperlipidemic rats for 6 weeks, and at the same time given Avena sativa in diet ( $200 \mathrm{~g} / \mathrm{Kg}$ diet).

Results:

The biochemical parameters showed highly significant increase in body weight, serum glucose, AST, ALT, GGT, LDH, urea, creatinine, total protein, albumin, total lipids, cholesterol, triglycerides and LDL-cholesterol, while there was highly significant decrease in HDLcholesterol.Many histopathological and histochemical changes were detected in liver tissue of the hyperlipidemic rats. Meanwhile, the treatment with oat ameliorated the biochemical parameters, histological and histochemical results
\end{abstract}

\section{Conclusion:}

It is recommend to use oat in diets for hyperlipidemic patients or those people who have hyperlipidemic family history.

Keywords:

Hyperlipidemia,Oat bran, Lipid profile, Albino rats, physiological parameters, histopathology and histochemistry.

\section{Introduction}

Hyperlipidemia (mainly increased level of total cholesterol (TC), triglycerides (TG) and low-density lipoprotein(LDL) cholesterol along with decrease in highdensity lipoprotein(HDL) cholesterol) is the predictor of coronary artery disease (CAD). Hyperlipidemia is an important risk factor in the initiation and progression of atherosclerotic impasse (Harrison et al., 2003).

The hyperlipidemia-lowering effect of dietary plants has been well studied and various plants were shown to be helpful in lowering plasma lipid levels and encouraging safety profile. Dietary plants therefore are considered to be useful means to prevent disorders such as atherosclerosis (Choudhary et al., 2005).

One of the most important plants used as hyperlipidemia-lowering effect in the folk medicine in Egypt is oat herb (Avena sativa). Oat is considered as an important source of water-soluble fibers, have long been recognized as a potential cholesterollowering dietary component (Davidson $\boldsymbol{e t}$ al., 1991).

The oat (Avena Sativa) is a species of cereal grains, and the seeds of this plant, are used 
as food for people and animals, especially poultry and horses. Oat is the only cereal containing a globulin or legume-like protein, avenalins, as the major $(80 \%)$ storage protein. Globulins are characterized by their water solubility, because of this property; oats may be turned into milk but not into bread. It is the more typical cereal proteins, such as gluten and prolamines. The minor protein of oat is a prolamine avenin. Oat protein is nearly equivalent in quality to soy protein which has been shown by the World Health Organization to be the equal to meat, milk, and egg protein (Anderson et al., 1990).

Oat bran contains soluble fibers, such as $\beta$ glucan, that increase bile acid excretion and thus decrease serum cholesterol (Reihner $\boldsymbol{e t}$ al., 1990). The beneficial effects of oat products on the lipoprotein profile are ascribed to their soluble fiber compound, $\beta$ glucan (Braaten et al., 1994).

$\beta$-glucan from oats is a non starch polysaccharide that is composed of $\beta$ $(1 \rightarrow 4)$-linked glucose units which are separated every 2-3 units by a single $\beta$ $(1 \rightarrow 3)$-linked glucose unit (Bell et al., 1999). $\beta$-glucan from barley (Bourdon $\boldsymbol{e t}$ al., 1999) or yeast (Nicolosi et al., 1999) has also been shown to be hypocholesterolemic.

Oat is a source of many compounds that exhibit antioxidant activity. Vitamin E, phytic acid, significant quantities of phenolic compounds, and avenanthramides are the most abundant antioxidant in oat, flavonoids and sterols are also present (Mensink and Katan, 1992; Peterson, 2001).

So,this study aimed to evaluate the possible treatment and protective effect of Avena sativa in hyperlipidemic rats.

\section{Material and methods}

\section{1-Experimental animals:}

The present work was carried out on thirty mature female albino rats $(150 \pm 20 \mathrm{~g})$. They were obtained from the Nile Company for Pharmaceutical and Chemical Industries. The experimental animals were randomly divided into six groups (5/group) and fed on rodent diet. The rats stayed for 3 weeks to adapt the place then the experimental steps were started.

\section{2-Experimental design:}

Six groups were used in this study each containing 5 female albino rats. The experiment lasts for 6 weeks.

1-The $1^{\text {st }}$ group: served as control (C).

2-The $2^{\text {nd }}$ group: hyperlipidemic rats (25\% fat \& $2 \%$ cholesterol) 3 weeks only then they were scarified (H3).

3-The $3^{\text {rd }}$ group: served as hyperlipidemic rats for 3 weeks then left other 3 weeks without any additional treatment as a recovery period ( $\mathrm{R})$.

4-The $4^{\text {th }}$ group: served as hyperlipidemic rats for 3 weeks then treated with Avena sativa for 3 weeks $(200 \mathrm{gm} / \mathrm{Kg}$ diet) $(\mathrm{H} 3 A)$. 5-The $5^{\text {th }}$ group: included hyperlipidemic rats $(25 \%$ fat $\& 2 \%$ cholesterol) for 6 weeks (H6).

6-The $6^{\text {th }}$ group: served as hyperlipidemic rats for 6 weeks, and at the same time they were given Avena sativa in the $\operatorname{diet}(200 \mathrm{gm} / \mathrm{Kg} \operatorname{diet}) \quad$ (H6A).

Each rat was weighted at the beginning and the end of the experiment and percentage of body weight changes were calculated.

\section{Collection of rat's serum}

At the end of the experiment, animals were decapitated and blood samples were collected from the retro-orbital plexus. The samples were collected in clean dry graduated centrifuge tubes and left for 20 minutes to clot, then centrifuged at 5000 rpm, for 15 minutes. Serum was separated and kept at $-20^{\circ} \mathrm{C}$ until analysis.

Serum glucose was estimated according to Trinder (1984). Aspartate transaminase (AST) was performed according to Bergmeyer (1978). Alanine transaminase (ALT) was determined according to Breuer (1996). $\gamma$-Glutamyltransferase $(\gamma$-GT) was done according to Szasz and Persijn (1974). Serum LDH (Lactate dehydrogenase) concentration was done according to the kinetic ultraviolet method of Young (1990). Measurement of Serum Urea was done according to the method of Patton and Crouch (1977). Serum 
creatinine was evaluated according to the method of Jaffe (1980). Serum total protein was performed by the method of Tietz (1994).Serum albumin was done by the method of Doumas et al. (1971).

Total lipids was done by the method of Kaplan (1984). Serum total cholesterol(T.C) was performed according to Henry et al. (1974) . Serum triglycerides(T.G) were determined according to the method of Fossati and Prencie (1982). Serum high density lipoproteins cholesterol (HDL-Cholesterol) was done according to Burstein (1970). The concentration of low density lipoproteins cholesterol (LDL-Cholesterol) in serum was estimated by the equation used by Friedewald et al. (1972) as follow: LDL - cholesterol $(\mathrm{mg} / \mathrm{dl})=$ Total cholesterol - HDL cholesterol $-\left(\frac{T . G}{5}\right)$

\section{The histological and histochemical results:}

Fresh specimens of liver were taken from the control and treated groups. The specimens were fixed in 10\% neutral buffer formol and Carnoy's fluid for the histological and histochemical studies. Sections were then cut at $5 \mu$ thickness and stained by haematoxylin and eosin stain according to the method of Drury \& Wallington (1980), periodic acid Schiff technique for demonstrating glycogen (Pearse,1977). Mercuric bromophenol blue method for detecting total protein (Mazia et al., 1953). Mallory's trichrome stain for demonstrating collagen fibers (Pearse, 1977).

\section{Statistical analysis:}

The data are expressed as means \pm standard errors (SE). The (T) test was used to elucidate the differences between treated and control groups (Snedecor and Cochran, 1980). A difference was considered significant at $\mathrm{p}<0.05$ or $\mathrm{p}<$ 0.01 .

\section{Results}

The percentage of body weight gain was highly significant increased $(\mathrm{P}<0.01)$ in all treated groups. Concerning serum glucose level, the present data showed sever hyperglycemia $(\mathrm{P}<0.01)$ in all the treated groups. (Table 1).

Results of the present study showed a high significant increase $(\mathrm{P}<0.01)$ in AST, ALT, GGT and LDH activities in all the treated groups when compared with the control rats (Table 2).Also, high significant increase $(\mathrm{P}<0.01)$ in serum urea and creatinine concentrations in all treated groups was detected(Table 3 ) with

high significant increase $(\mathrm{P}<0.01)$ in serum total protein and albumin concentrations in all the treated groups when compared with the control one during the experimental period (Table 4). Globulin concentration showed insignificant change in all treated groups (Table 4). All treated groups also showed insignificant change in albumin/globulin ratio (A/G ratio) except in the group that fed hyperlipidemic diet for 6 weeks where it showed highly significant increase $(\mathrm{P}<0.01)$ as compared with the control group (Table 4).

A high significant increase $(\mathrm{P}<0.01)$ in serum total lipids was realized except in the group that treated with hperlipidemic diet for 3 weeks followed by oat for another 3 weeks which showed a significant increase $(\mathrm{P}<0.05)$. Concerning liver total lipids highly significant increase $(\mathrm{P}<0.01)$ was recorded (except in the group that treated with hperlipidemic diet for 3 weeks followed by oat for another 3 weeks) which showed highly significant decrease $(\mathrm{P}<$ $0.01)$. Cholesterol and triglycerides, showed highly significant increase $(\mathrm{P}<0.01)$ in all the treated groups. HDL-cholesterol showed highly significant decrease $(\mathrm{P}<$ $0.01)$ in all the treated groups. Concerning LDL-cholesterol, highly significant increase $(\mathrm{P}<0.01)$ was observed in all the treated groups. HDL/LDL ratio showed highly significant decrease $(\mathrm{P}<0.01)$ in all the treated groups when compared with the control group (Table 5).

Hyperlipidemia for 6 weeks elevated all the studied parameters, while feeding oat for 3 weeks after stopping of fat diets recorded the lowest results in these parameters .

Normal histological pattern of liver tissue of a control rat was detected in figs. (1\&2)Hyperlipidemic rats of groups $\mathrm{H} 3$ or H6 showed many pathological changes in 
the liver tissue and the changes were more pronounced in rats of group H6. These changes include: highly distorted and ruptured endothelial lining of the blood vessels, increased lymphocytic infiltration in the portal area, haemolysed RBCs inside the blood vessels, degenerated and vacuolated hepatocytes with increased Kupffer and fatty cells (Figs. 3-5).A slight amelioration was noticed in liver tissue of rats of the recovery group (Figs. 6\&7).

Noticeable signs of recovery were noticed in liver tissue of rats of groups H3A or H6A, but increased lymphocytic infiltration , haemolysed RBCs in the portal areas and distorted bile canaliculi with vacuolated hepatocytes were still observed (Figs.8,9,10 and 11).

Normal distribution of collagen fibers was observed in figs.( 12\&13).Increased collagen fibers were observed in liver tissue of groups H3 or H6, the recovery group and those treated with fats and Avena sativa for 3 or 6 weeks ( Figs. 14,15,16,17).

Normal distribution of total protein in the hepatic tissue of a control rat was observed in figs (18\&19).
Highly reduced total protein was observed in liver tissue of group H3 or H6 (Figs. 20 $\& 21$ ), but the $\mathrm{R}$ group showed a mild decrease. Meanwhile, normal total protein was observed in hepatocytes of liver tissue of groups H3A or H6A.

Normal distribution of polysaccharides was observed in figs. (22\&23). Highly reduced polysaccharides were detected in liver tissue of groups H3 and H6 (Figs. 24 \& 25), but thickened arterial walls showed increased stain affinity. Moderate stain affinity was detected in liver tissue of group $\mathrm{R}$ with normal stain affinity was observed in walls of the blood vessels (Figs. $26 \&$ 27). Nearly normal glycogen content was noticed in liver tissue of groups $\mathrm{H} 3 \mathrm{~A}$ and H6A (Figs.28 \& 29).

Concerning all the previous biochemical parameters, histological and histopathological changes it was found that using oat was better than only stop fats after hyperlipidemic diets without any additional treatment (recovery groups).

Table (1): Percentage of body weight change and Serum glucose level $(\mathrm{mg} / \mathrm{dl})$ in female albino rats after induction of hyperlipidemia and treating with oat (Avena sativa).

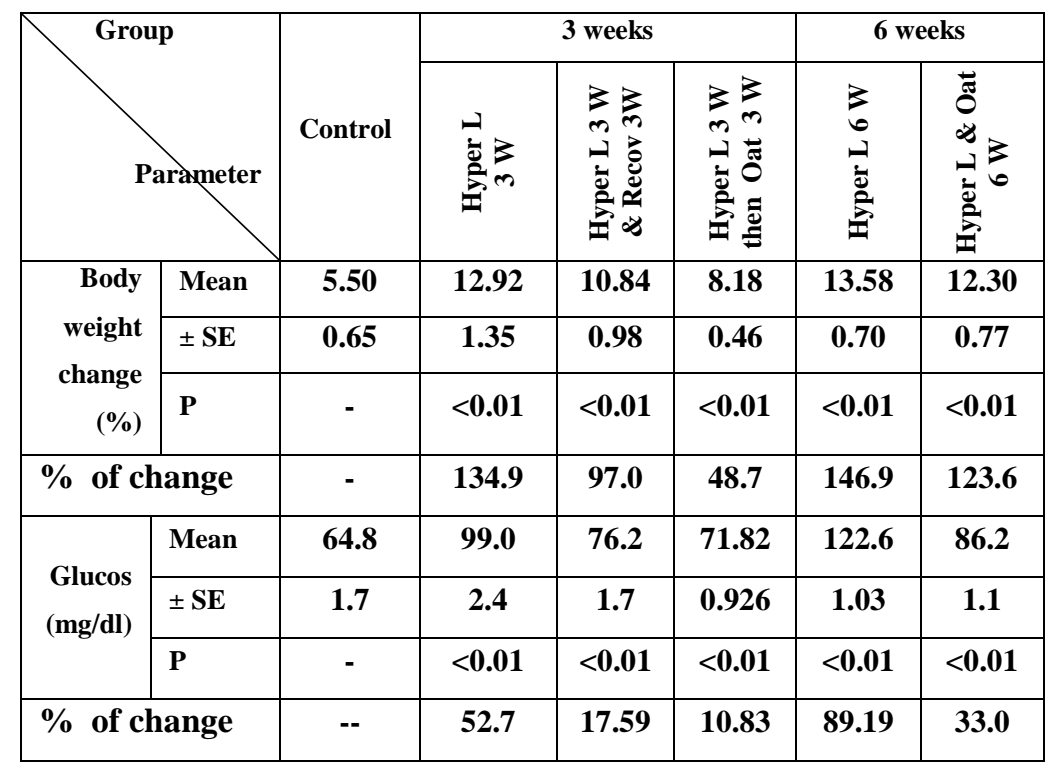

Hyper $L$ = Hyperlipidemia N.S = non significan
Recov = recovery

$3 \mathrm{~W}=3$ weeks

$6 \mathrm{~W}=6 \mathrm{Weeks}$ 
Table (2): Aspartate transaminase (AST), Alanine transaminase (ALT) Glutamyl transferase (GGT) and Lactate dehydrogenase (LDH) activities in female albino rats after induction of hyperlipidemia and treating with oat (Avena sativa).

\begin{tabular}{|c|c|c|c|c|c|c|c|}
\hline \multicolumn{2}{|c|}{ Group } & \multirow[b]{2}{*}{ Control } & \multicolumn{3}{|c|}{3 weeks } & \multicolumn{2}{|c|}{6 weeks } \\
\hline \multicolumn{2}{|c|}{ Parameter } & & 离 & 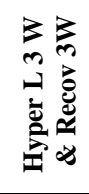 & 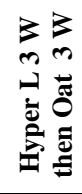 & 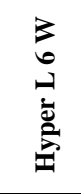 & 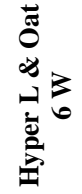 \\
\hline \multirow{3}{*}{$\begin{array}{r}\text { AST } \\
\text { (U/L) }\end{array}$} & Mean & 32.5 & 89.8 & 87.6 & 50.2 & 114.6 & 80.8 \\
\hline & $\pm \mathbf{S E}$ & 0.8 & 0.96 & 2.99 & 0.96 & 2.3 & 0.82 \\
\hline & $\mathbf{P}$ & - & $<0.01$ & $<0.01$ & $<0.01$ & $<0.01$ & $<0.01$ \\
\hline \multicolumn{2}{|c|}{$\%$ of change } & - & 176.3 & 169.5 & 54.4 & 252.6 & 148.6 \\
\hline \multirow{3}{*}{$\begin{array}{c}\text { ALT } \\
\text { (U/L) }\end{array}$} & Mean & 23.2 & 73.4 & 53.0 & 31.4 & 107.8 & 35.2 \\
\hline & $\pm \mathbf{S E}$ & 1.4 & 1.8 & 1.1 & 1.2 & 2.3 & 2.1 \\
\hline & $\mathbf{P}$ & - & $<0.01$ & $<0.01$ & $<0.01$ & $<0.01$ & $<0.01$ \\
\hline \multicolumn{2}{|c|}{$\%$ of change } & - & 216.3 & 128.4 & 35.3 & 364.6 & 51.7 \\
\hline \multirow{3}{*}{$\begin{array}{c}\text { GGT } \\
\text { (U/L) }\end{array}$} & Mean & 26.2 & 40.8 & 39.6 & 32.7 & 45.4 & 39.4 \\
\hline & $\pm \mathbf{S E}$ & 1.85 & 0.6 & 0.57 & 0.675 & 1.35 & $\mathbf{0 . 5 7 0}$ \\
\hline & $\mathbf{P}$ & - & $<0.01$ & $<0.01$ & $<0.01$ & $<0.01$ & $<0.01$ \\
\hline \multicolumn{2}{|c|}{$\%$ of change } & - & 55.7 & 51.1 & 24.8 & 73.2 & 50.3 \\
\hline \multirow{3}{*}{$\begin{array}{c}\text { LDH } \\
\text { (U/L) }\end{array}$} & Mean & 177.8 & 363.0 & 244.0 & 190.8 & 391.6 & 237.6 \\
\hline & $\pm \mathbf{S E}$ & 2.8 & 1.9 & 2.26 & 0.96 & 4.3 & 9.0 \\
\hline & $\mathbf{P}$ & - & $<0.01$ & $<0.01$ & $<0.01$ & $<0.01$ & $<0.01$ \\
\hline \multicolumn{2}{|c|}{$\%$ of change } & - & 104.1 & 37.2 & 7.3 & 120.2 & 33.6 \\
\hline
\end{tabular}

Hyper $L=$ Hyperlipidemia

$\operatorname{Recov}=$ recovery

$3 \mathrm{~W}=3$ weeks

$6 \mathrm{~W}=6$ Weeks

N.s = non significant 
Table (3): Serum urea and creatinine levels in female albino rats afte induction of hyperlipidemia and treating with oat (Avena sativa).

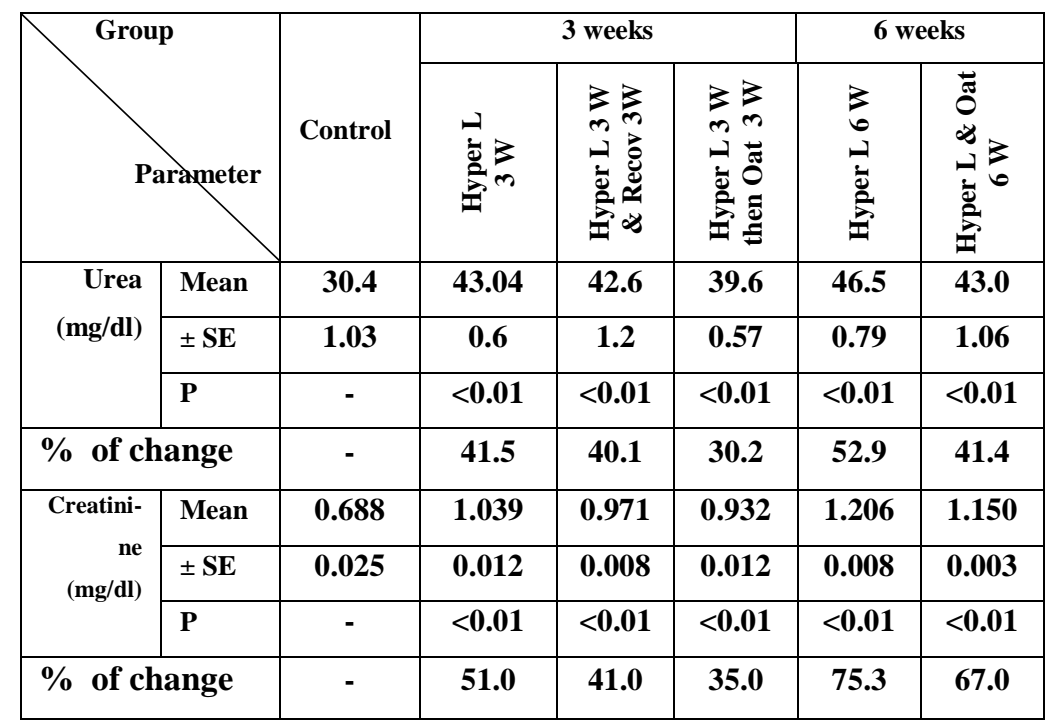

Hyper $L=$ Hyperlipidemia $\quad$ Recov $=$ recovery $\quad 3 \mathrm{~W}=3$ weeks $\quad 6 \mathrm{~W}=6$ Weeks

N.s = non significant

Table (4): Total protein, Albumin, Globulin concentrations an Albumin/Globulin ratio (A/G ratio) in female albino rats after induction of hyperlipidemia and treating with oat (Avena sativa).

\begin{tabular}{|c|c|c|c|c|c|c|c|c|}
\hline & Grou & & & & 3 weeks & & & \\
\hline & & rameter & Control & 离赵 & 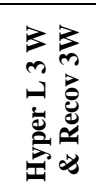 & 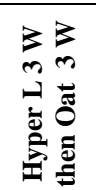 & 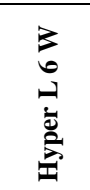 & 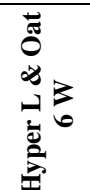 \\
\hline & Total & Mean & 6.7 & 8.46 & 8.0 & 7.74 & 9.12 & 8.1 \\
\hline & protein & $\pm \mathrm{SE}$ & 0.127 & 0.17 & 0.145 & 0.120 & 0.065 & 0.079 \\
\hline & & $\mathbf{P}$ & - & $<0.01$ & $<0.01$ & $<0.01$ & $<0.01$ & $<0.01$ \\
\hline & $\%$ of ch & ange & - & 26.2 & 19.4 & 15.5 & 36.1 & 20.8 \\
\hline & Albumin & Mean & 4.32 & 5.7 & 5.4 & 4.9 & 6.5 & 5.52 \\
\hline & & $\pm \mathrm{SE}$ & 0.143 & 0.065 & 0.103 & 0.127 & 0.096 & 0.143 \\
\hline & & $\mathbf{P}$ & - & $<0.01$ & $<0.01$ & $<0.01$ & $<0.01$ & $<0.01$ \\
\hline & $\%$ of ch & ange & - & 31.9 & 25.0 & 13.4 & 50.4 & 27.7 \\
\hline & Globulin & Mean & 2.38 & 2.74 & 2.56 & 2.84 & 2.6 & 2.58 \\
\hline & & $\pm \mathrm{SE}$ & 0.163 & 0.160 & 0.216 & 0.210 & 0.061 & 0.185 \\
\hline & & $\mathbf{P}$ & - & N.S & N.S & N.S & N.S & N.S \\
\hline & $\%$ of $\mathrm{ch}$ & ange & - & 15.1 & 7.5 & 19.3 & 9.2 & 8.40 \\
\hline & $\mathbf{A} / \mathbf{G}$ & Mean & 1.85 & 2.106 & 2.182 & 1.764 & 2.512 & 2.184 \\
\hline & ratio & $\pm \mathrm{SE}$ & 0.177 & 0.128 & 0.249 & 0.187 & 0.094 & 0.214 \\
\hline & & $\mathbf{P}$ & - & N.S & N.S & N.S & $<0.01$ & N.S \\
\hline & $\%$ of $\mathrm{cl}$ & ange & - & 13.8 & 17.9 & -4.6 & 35.7 & 18.0 \\
\hline Hyper I & lipid & & & ery & & -3 & & \\
\hline
\end{tabular}


Table (5): The level of serum total lipids, liver total lipids, cholesterol, triglycerides, HDL-cholesterol, LDL-cholesterol and HDL/LDL ratio in female albino rats after induction of hyperlipidemia and treating with oat (Avena sativa).

\begin{tabular}{|c|c|c|c|c|c|c|c|}
\hline \multicolumn{2}{|c|}{ Group } & \multirow[b]{2}{*}{ Control } & \multicolumn{3}{|c|}{3 weeks } & \multicolumn{2}{|c|}{6 weeks } \\
\hline \multicolumn{2}{|c|}{ Parameter } & & $\underset{\square}{\infty}$ & 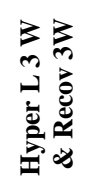 & 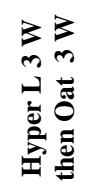 & $\begin{array}{l}3 \\
0 \\
0 \\
\vdots \\
\vdots \\
0\end{array}$ & 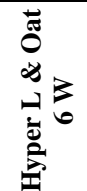 \\
\hline \multirow{3}{*}{$\begin{array}{r}\text { Serum } \\
\text { total } \\
\text { lipids } \\
(\mathrm{g} / \mathrm{l})\end{array}$} & Mean & 5.16 & 6.26 & 5.92 & 5.58 & 6.38 & 6.06 \\
\hline & $\pm \mathbf{S E}$ & 0.125 & 0.075 & 0.041 & 0.11 & 0.17 & 0.05 \\
\hline & $\mathbf{P}$ & - & $<0.01$ & $<0.01$ & $<0.05$ & $<0.01$ & $<0.01$ \\
\hline \multicolumn{2}{|c|}{$\%$ of change } & - & 21.3 & 14.7 & 8.1 & 23.6 & 17.4 \\
\hline \multirow{3}{*}{$\begin{array}{r}\text { Liver } \\
\text { total } \\
\text { lipids } \\
\text { (g/l) }\end{array}$} & Mean & 4.52 & 5.64 & 5.34 & 3.72 & 7.46 & 5.92 \\
\hline & $\pm \mathbf{S E}$ & 0.21 & 0.13 & 0.125 & 0.14 & 0.16 & 0.151 \\
\hline & $\mathbf{P}$ & - & $<0.01$ & $<0.01$ & $<0.01$ & $<0.01$ & $<0.01$ \\
\hline \multicolumn{2}{|c|}{$\%$ of change } & - & 24.7 & 18.1 & -17.6 & 65.04 & 30.97 \\
\hline \multirow{3}{*}{$\begin{array}{r}\text { Cholest- } \\
\text { erol } \\
(\mathrm{mg} / \mathrm{dl})\end{array}$} & Mean & 83.54 & 135.0 & 120.4 & 95.4 & 150.0 & 140.4 \\
\hline & $\pm \mathbf{S E}$ & 2.31 & 0.79 & 0.570 & 0.570 & 0.790 & 1.03 \\
\hline & $\mathbf{P}$ & - & $<0.01$ & $<0.01$ & $<0.01$ & $<0.01$ & $<0.01$ \\
\hline \multicolumn{2}{|c|}{$\%$ of change } & - & 61.5 & 44.1 & 14.1 & 79.5 & 68.06 \\
\hline \multirow{3}{*}{$\begin{array}{r}\text { Triglyc- } \\
\text { erides } \\
(\mathrm{mg} / \mathrm{dl})\end{array}$} & Mean & 93.2 & 140.4 & 124.6 & 115.4 & 161.2 & 139.2 \\
\hline & $\pm \mathrm{SE}$ & 2.77 & 0.570 & 0.570 & 2.07 & 0.65 & 0.96 \\
\hline & $\mathbf{P}$ & - & $<0.01$ & $<0.01$ & $<0.01$ & $<0.01$ & $<0.01$ \\
\hline \multicolumn{2}{|c|}{$\%$ of change } & - & 50.6 & 33.6 & 23.8 & 72.9 & 49.3 \\
\hline \multirow{3}{*}{$\begin{array}{r}\text { HDL- } \\
\text { cholester- } \\
\text { ol } \\
(\mathrm{mg} / \mathrm{dl})\end{array}$} & Mean & 35.4 & 29.6 & 30.2 & 32.0 & 22.0 & 30.4 \\
\hline & $\pm \mathbf{S E}$ & 0.57 & 0.75 & 0.74 & 0.79 & 0.79 & 0.83 \\
\hline & $\mathbf{P}$ & - & $<0.01$ & $<0.01$ & $<0.01$ & $<0.01$ & $<0.01$ \\
\hline \multicolumn{2}{|c|}{$\%$ of change } & - & -16.3 & -14.6 & -9.6 & -37.8 & -14.1 \\
\hline \multirow{3}{*}{$\begin{array}{c}\text { LDL- } \\
\text { Cholest- } \\
\text { erol } \\
(\mathrm{mg} / \mathrm{dl})\end{array}$} & Mean & 29.5 & 77.3 & 65.28 & 40.3 & 95.76 & 82.16 \\
\hline & $\pm \mathrm{SE}$ & 2.39 & 1.39 & 0.167 & 1.32 & 1.50 & 1.54 \\
\hline & $\mathbf{P}$ & - & $<0.01$ & $<0.01$ & $<0.01$ & $<0.01$ & $<0.01$ \\
\hline \multicolumn{2}{|c|}{$\%$ of change } & - & 162.0 & 121.2 & 36.6 & 224.6 & 178.5 \\
\hline \multirow{3}{*}{$\begin{array}{r}\text { HDL/L } \\
\text { DL ratio }\end{array}$} & Mean & 1.218 & 0.376 & 0.458 & 0.794 & 0.224 & 0.364 \\
\hline & $\pm \mathrm{SE}$ & 0.089 & 0.0168 & 0.0129 & 0.0453 & 0.010 & 0.0175 \\
\hline & $\mathbf{P}$ & - & $<0.01$ & $<0.01$ & $<0.01$ & $<0.01$ & $<0.01$ \\
\hline \multicolumn{2}{|c|}{$\%$ of change } & - & -69.1 & -62.3 & -34.8 & -81.6 & -70.1 \\
\hline
\end{tabular}

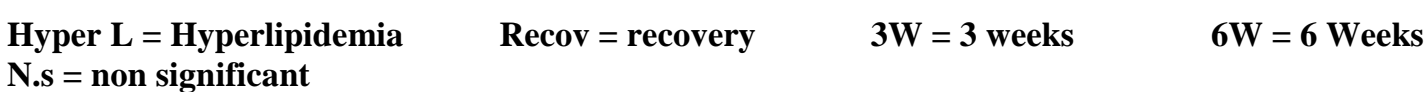




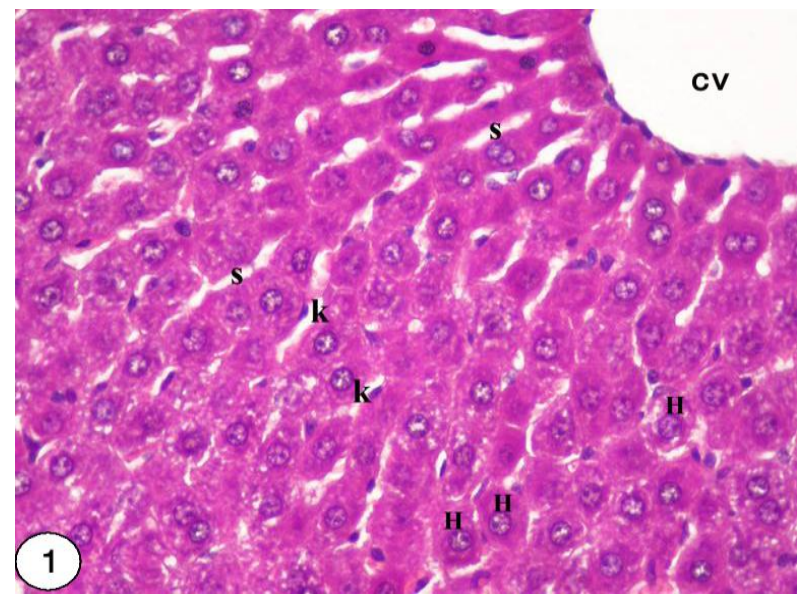

Figs.( 1 \& 2 ) showing photomicrographs of liver tissue of a control rat.

1- Showing the central vein ( $\mathrm{cv}$ ), sinusoidal spaces ( s ), kupffer cells ( $\mathrm{k}$ ) and hepatocytes ( $\mathrm{H}$ ).

( HX \& E X100)

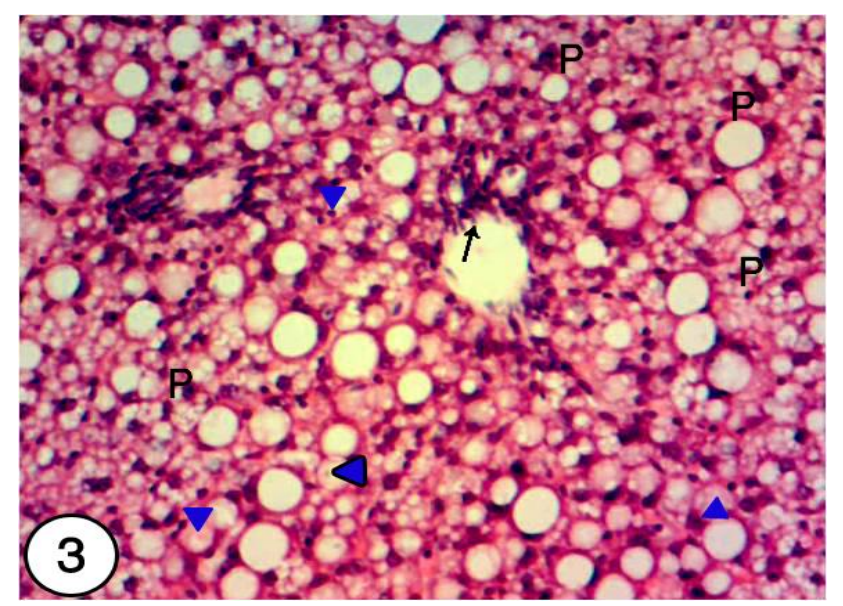

Figs . ( 3,4 \& 5 ) showing photomicrographs of liver tissue of rats treated with fats ( hyperlipidemia ) for 3 weeks only.

3- Showing numerous fatty cells, lymphocytic infiltration around the distorted central vein $(\boldsymbol{\lambda})$, lots of vacuolated hepatocytes $(\wedge)$ many pyknotic nuclei ( $\mathrm{p}$ ).

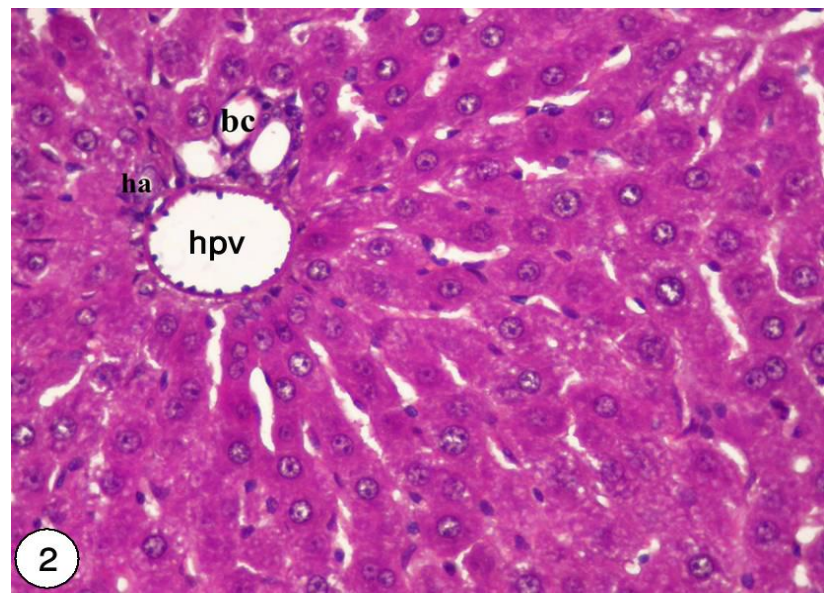

2- Showing the portal area which contains a branch of the hepatic portal vein ( hpv), bile canaliculi ( bc ) and a branch of the hepatic artery ( ha ).

( HX \& E X100)

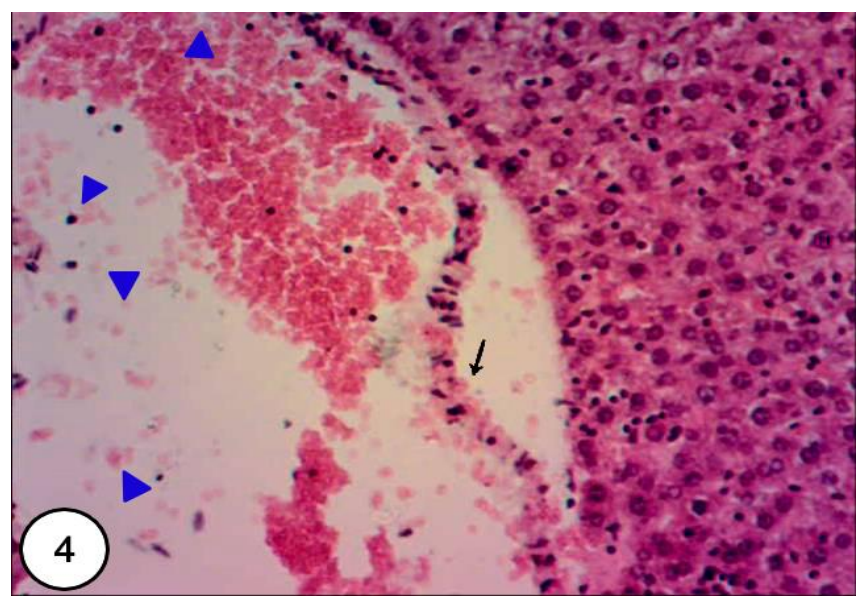

4- Showing delaminated endothelial lining of the central vein

( $\boldsymbol{\nearrow})$ and haemolysed RBCs $(\wedge)$.

( HX \& E X100 ) 


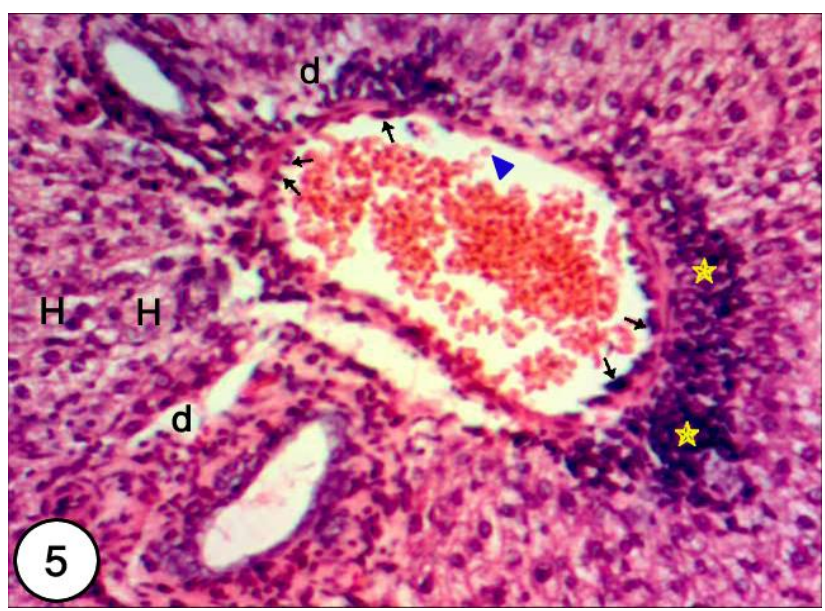

5 -Showing highly affected portal areas with enlarged nuclei of the endothelial lining of the branch of the hepatic portal vein $(\boldsymbol{\lambda})$, haemolysed RBCs $(\wedge)$, highly distorted bile canaliculi

( bc ), increased lymphocytic infiltration ( ), numerous vacuolated hepatocytes $(\mathrm{H})$ and degenerated haepatocytes in the highly expanded empty spaces (d).

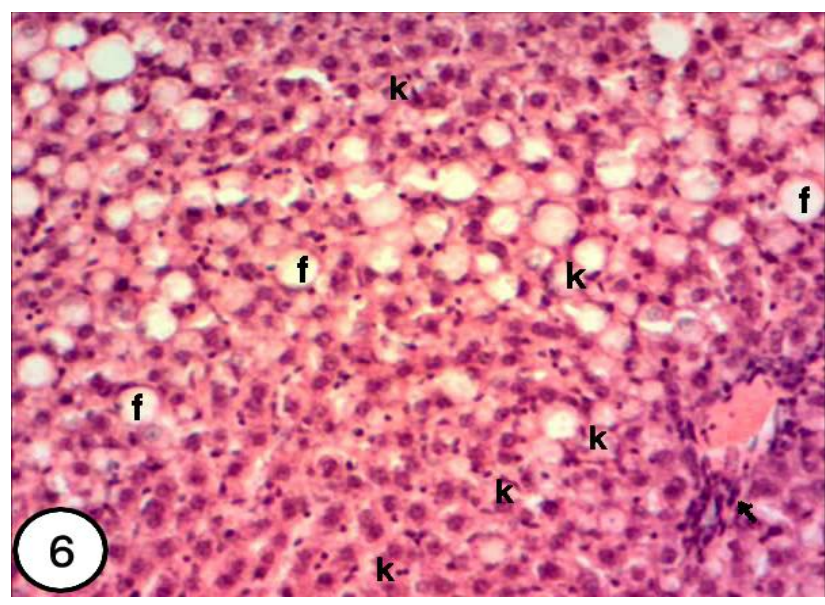

Figs . ( 6 \& 7 ) showing photomicrographs of liver tissue of rats treated with fats for 3 weeks and left 3 weeks for recovery.

( HX \& E X100 )

6- Showing lymphocytic infiltration around the central vein $(\boldsymbol{\lambda})$ ، increased kuffer cells $(\mathrm{k})$, fatty degeneration (F) with many vacuolated hepatocytes and haemolysed RBCs inside the central vein.

( HX \& E X100 )

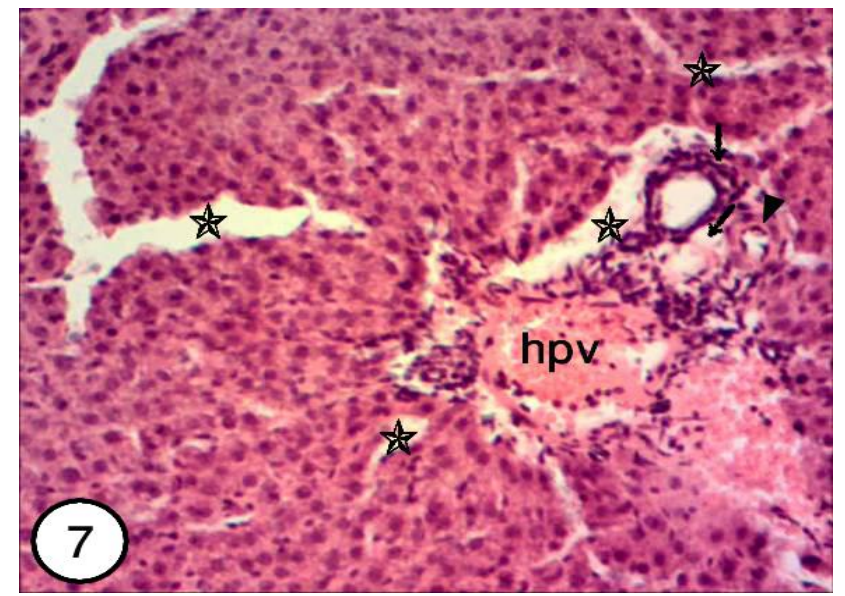

Fig. (7) Showing elongated and dilated hepatic portal vein ( hpv ), numerous empty spaces around the portal area and in between hepatocytes ( $\boldsymbol{L}^{\wedge}$ ), distorted walls of bile canaliculi $(\pi)$ and branches of the hepatic arteries $(\wedge)$ with haemolysed RBCs inside hpv and increased lymphocytic infiltration in and around the portal areas.

( HX \& E X100 ).

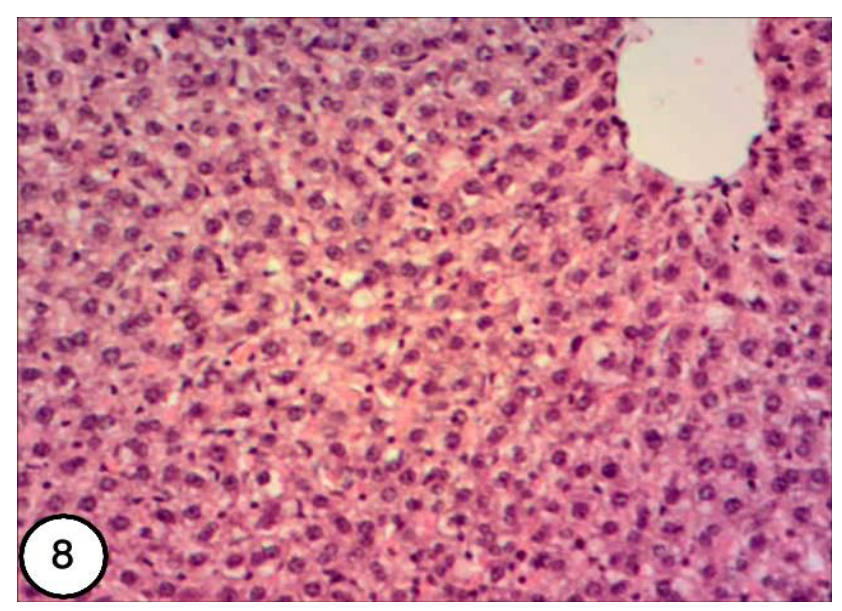

Fig.. (8) showing noticeable signs of recovery in the liver tissue of a rat treated with fats for 3 weeks then 3 weeks with Avena sativa.

Notice well developed hepatocytes and blood vessels, but lymphocytic infiltration is still observed in the portal area with haemolysed RBCs.

( HX \& E X100). 


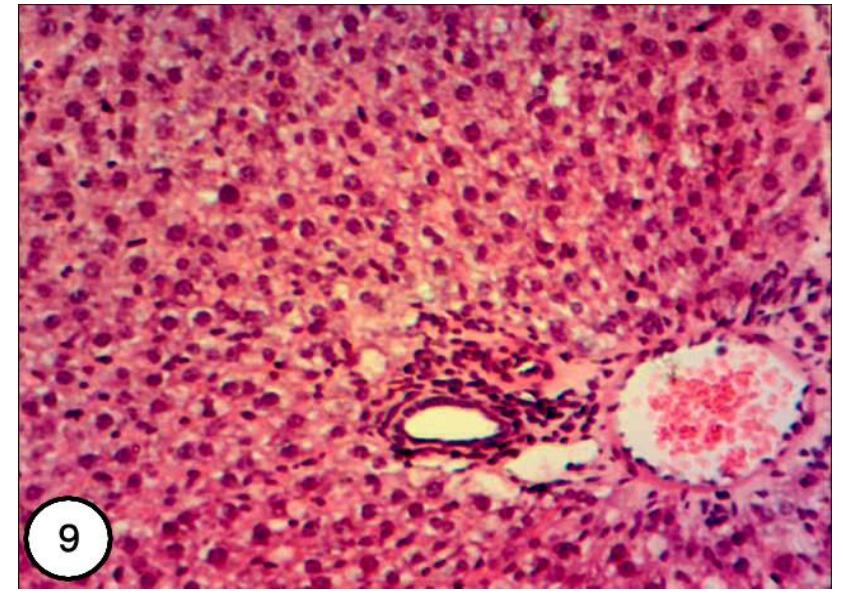

Fig.. (9) showing noticeable signs of recovery in the liver tissue of a rat treated with fats for 3 weeks then 3 weeks with Avena sativa.

Notice well developed hepatocytes and blood vessels, but lymphocytic infiltration is still observed in the portal area with haemolysed RBCs.

(HX \& E X100).

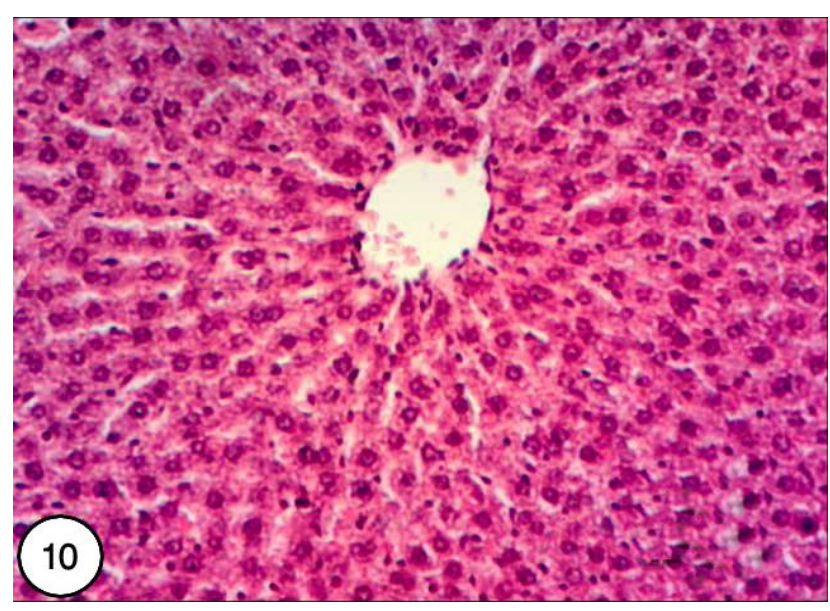

Fig. ( 10 ) showing photomicrographs of liver tissue of a rat treated with fats and Avena sativa for 6 weeks simultaneously. Notice: nearly complete recovery in the central area, while, the portal area showed ruptured endothelial lining of the dilated hpv and distorted and thickened walls of the bile canaliculi. Vacuolation was observed in some hepatocytes.

(HX \& E X100).

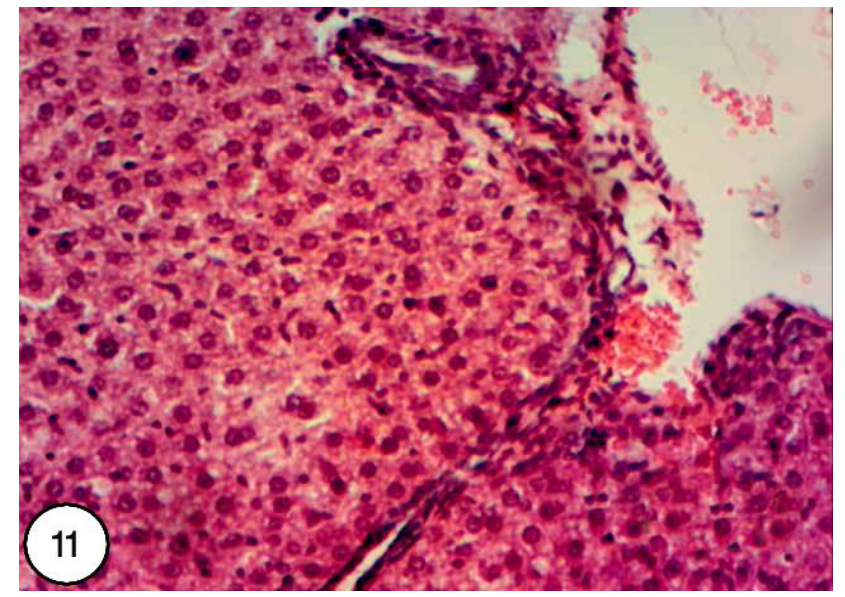

Fig. ( 11 ) showing photomicrographs of liver tissue of a rat treated with fats and Avena sativa for 6 weeks simultaneously. Notice: nearly complete recovery in the central area, while, the portal area showed ruptured endothelial lining of the dilated hpv and distorted and thickened walls of the bile canaliculi. Vacuolation was observed in some hepatocytes.

(HX \& E X100).

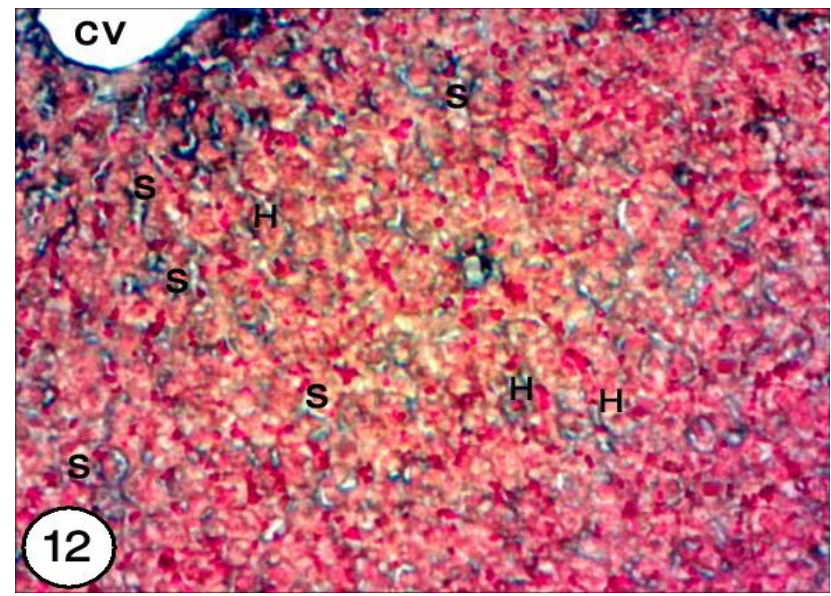

Fig.( 12) showing normal distribution of collagen fibers in the liver tissue of a control rat. Notice thin collagen bundles supporting the central vein (cv), hepatocytes $(\mathrm{H})$, sinusoidal spaces $(\mathrm{S})$, hpv and walls of bile canaliculi.

( Mallory's trichrome stain X 100 ) 


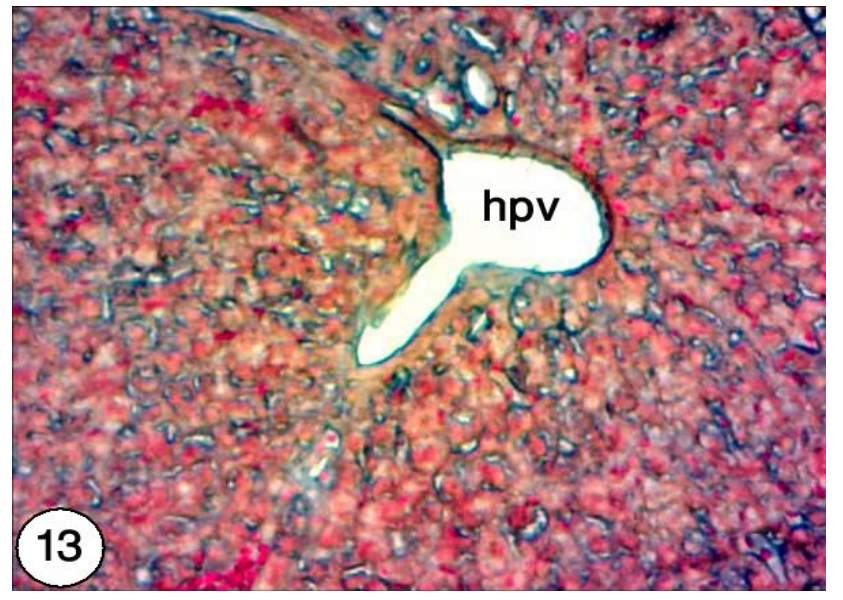

Fig.( 13) showing normal distribution of collagen fibers in the liver tissue of a control rat. Notice thin collagen bundles supporting the central vein (cv), hepatocytes $(\mathrm{H})$, sinusoidal spaces ( $\mathrm{S}$ ), hpv and walls of bile canaliculi.

( Mallory's trichrome stain X 100 )

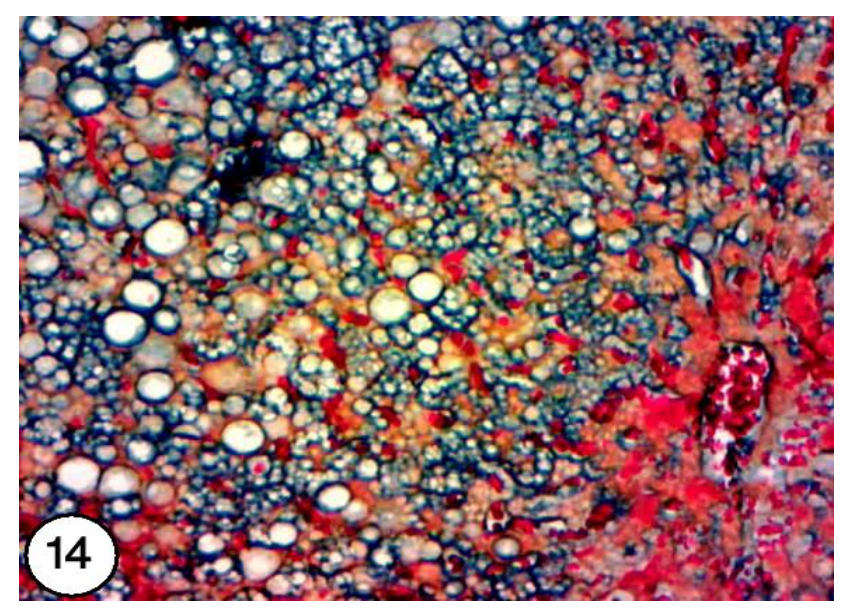

Fig.( 14 ) showing increased collagen fibers in the liver tissue of a rat treated with fats ( hyperlipidemia ) for 3 weeks only. Collagen fibers increased around the hepatocytes, branches of the hepatic portal vein, hepatic artery, while, collagen fibers decreased in the wall of the central vein $(\pi)$.

( Mallory's trichrome stain X 100 )

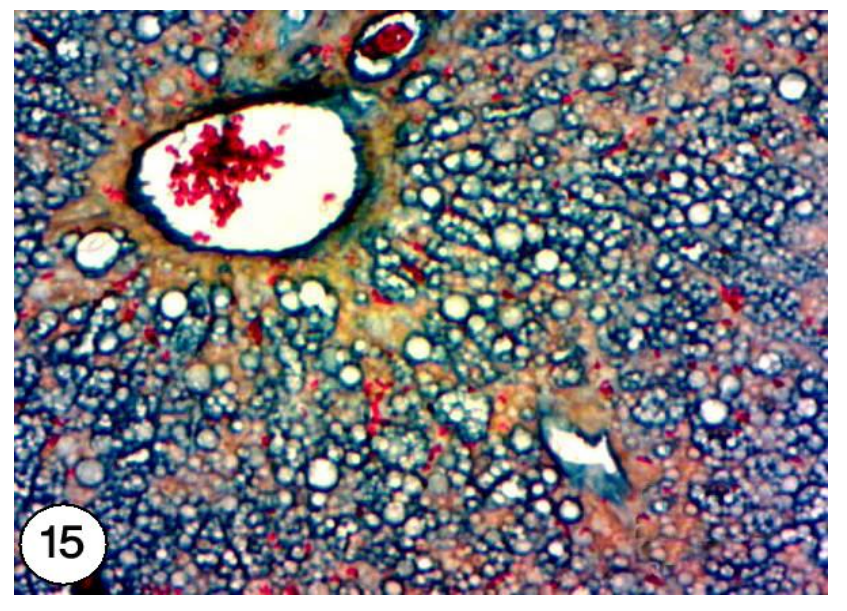

Fig.( 15 ) showing increased collagen fibers in the liver tissue of a rat treated with fats ( hyperlipidemia ) for 3 weeks only. Collagen fibers increased around the hepatocytes, branches of the hepatic portal vein , hepatic artery, while, collagen fibers decreased in the wall of the central vein $(\pi)$.

( Mallory's trichrome stain X 100 )

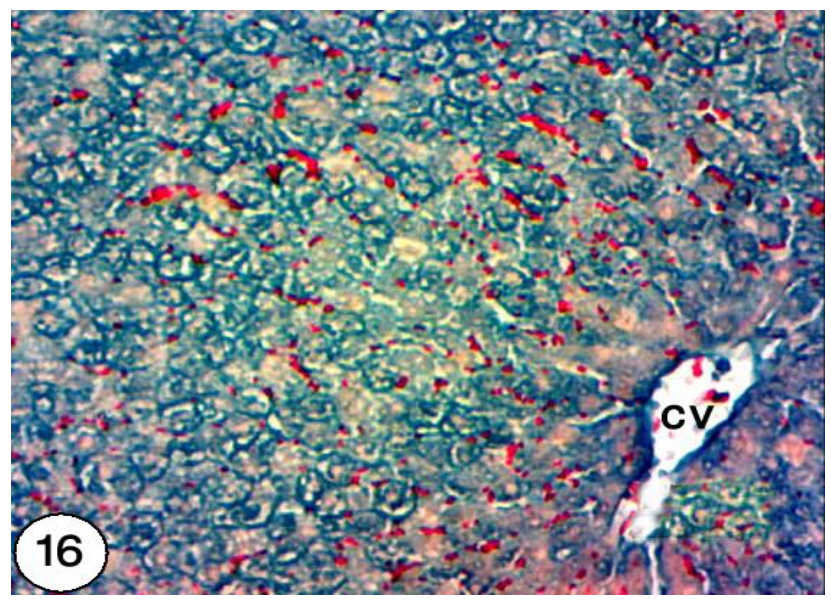

Fig.( 16) showing distribution of collagen fibers in the liver tissue of a rat treated with fats and Avena sativa for 6 weeks simultaneously.

( Mallory's trichrome stain X 100 ) 


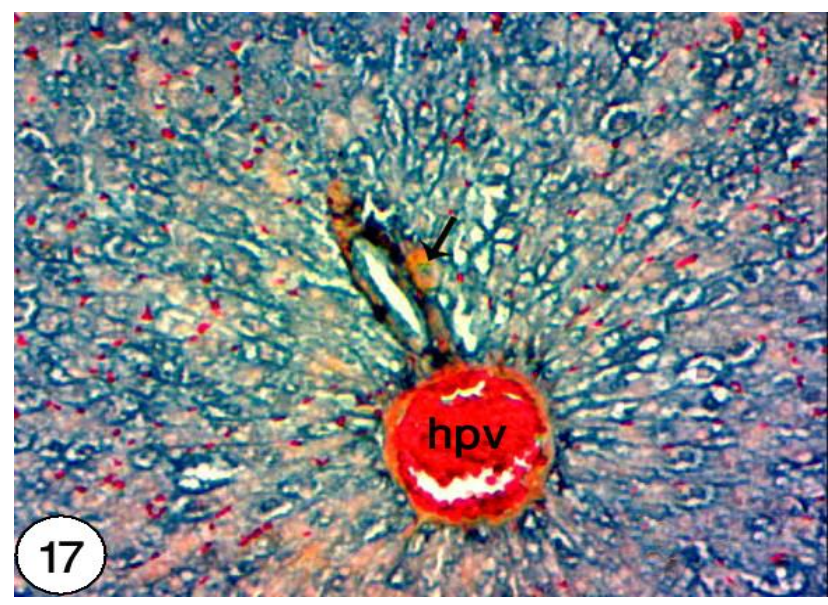

Fig.( 17) showing distribution of collagen fibers in the liver tissue of a rat treated with fats and Avena sativa for 6 weeks simultaneously.

( Mallory's trichrome stain X 100 )

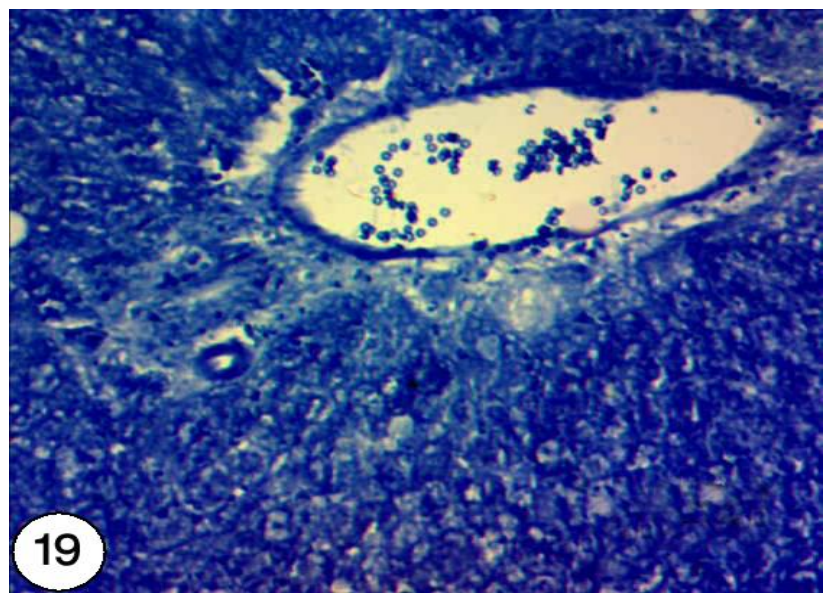

Fig.( 19 ) showing normal distribution of total proteins in the central and portal areas in the liver tissue of a control rat.

( Mercuric bromophenol blue X 100 )

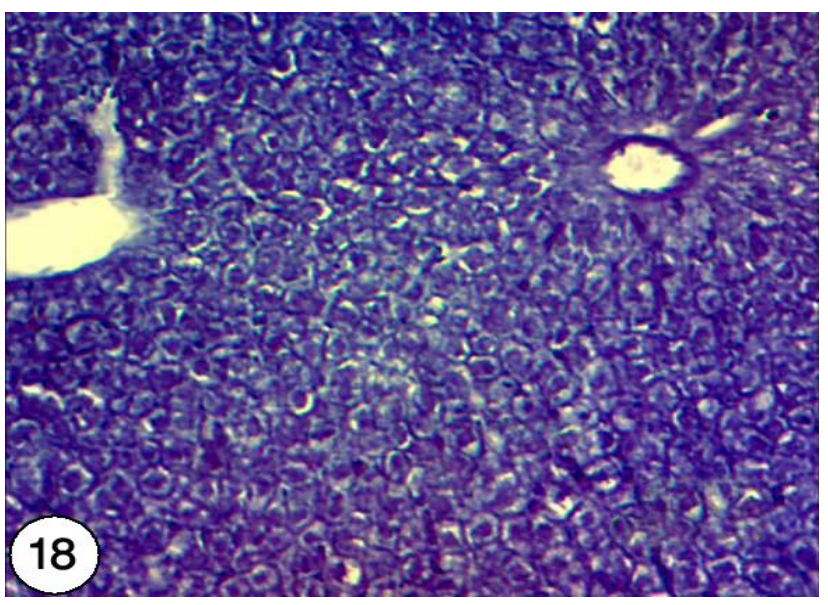

Fig.( 18 ) showing normal distribution of total proteins in the central and portal areas in the liver tissue of a control rat.

( Mercuric bromophenol blue X 100 )

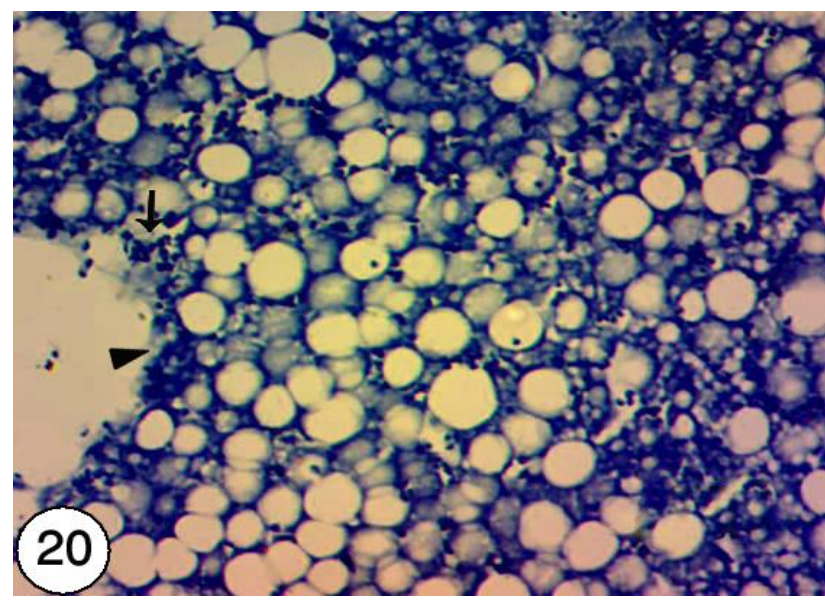

Fig.( 20) showing highly reduced total proteins in hepatocytes, walls of the central vein ,hepatic portal vein , bile canaliculi in the liver tissue of rats treated with fats only for 6 weeks. Notice that congested and dilated sinusoidal spaces contained deeply stained RBCs $(\boldsymbol{\Pi})$, the highly distorted central vein appeared faintly stained $(\wedge)$.

(Mercuric bromophenol blue X 100 ) 


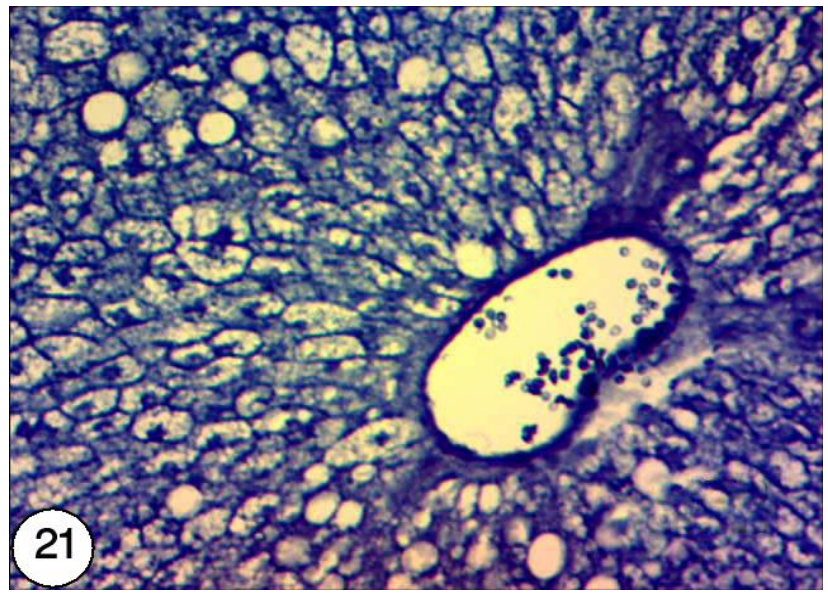

Fig.( 21) showing highly reduced total proteins in hepatocytes, walls of the central vein ,hepatic portal vein , bile canaliculi in the liver tissue of rats treated with fats only for 6 weeks. Notice that congested and dilated sinusoidal spaces contained deeply stained RBCs $(\boldsymbol{\lambda})$, the highly distorted central vein appeared faintly stained $\left({ }^{\wedge}\right)$.

(Mercuric bromophenol blue X 100 )

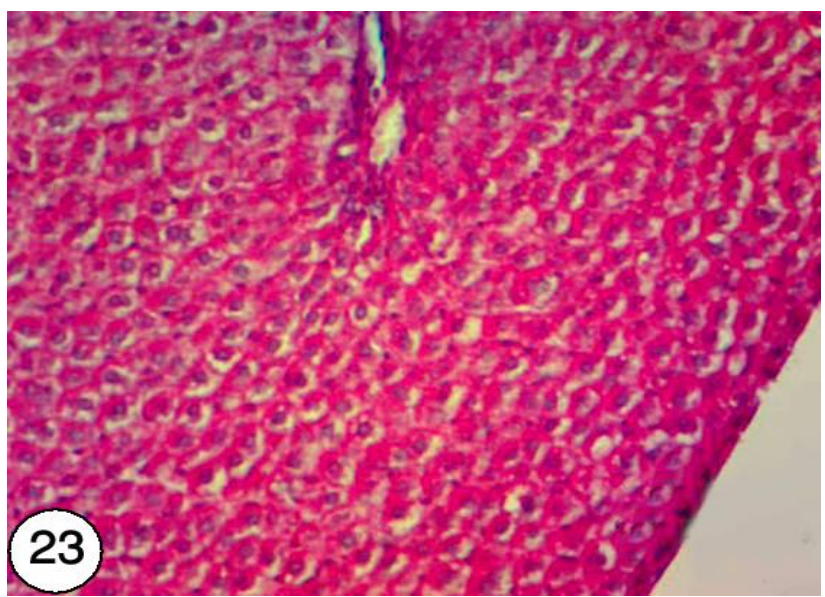

Fig.( 23) showing normal glycogen content in the central and portal areas of liver tissue of a control rat.

( PAS X 100).

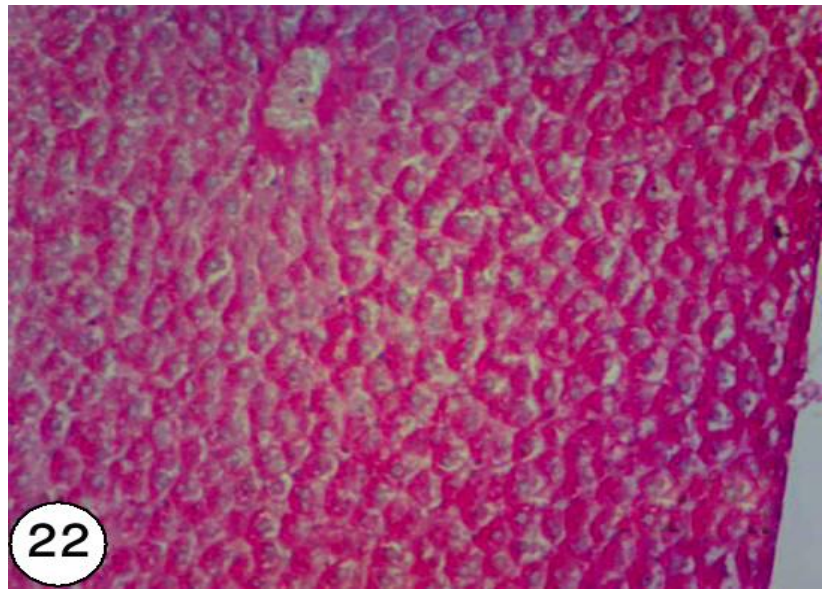

Fig.( 22) showing normal glycogen content in the central and portal areas of liver tissue of a control rat.

( PAS X 100).

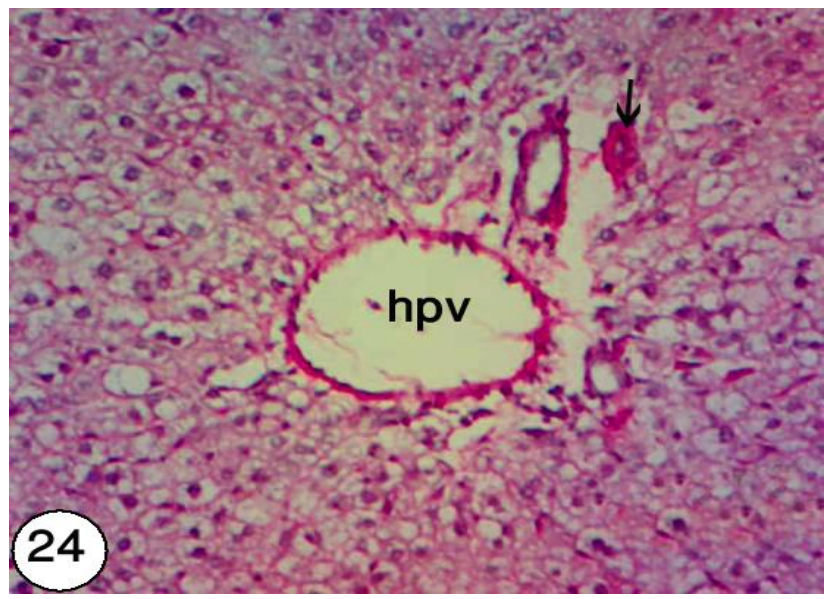

Fig.( 24) showing glycogen distribution in the liver tissue of a rat treated with fats only for 6 weeks .

Notice : Highly depleted hepatocytes in the portal and central areas, endothelia lining of the central vein with increased stain affinity in the thickened arterial wall $(\lambda)$.

(PAS X 100). 


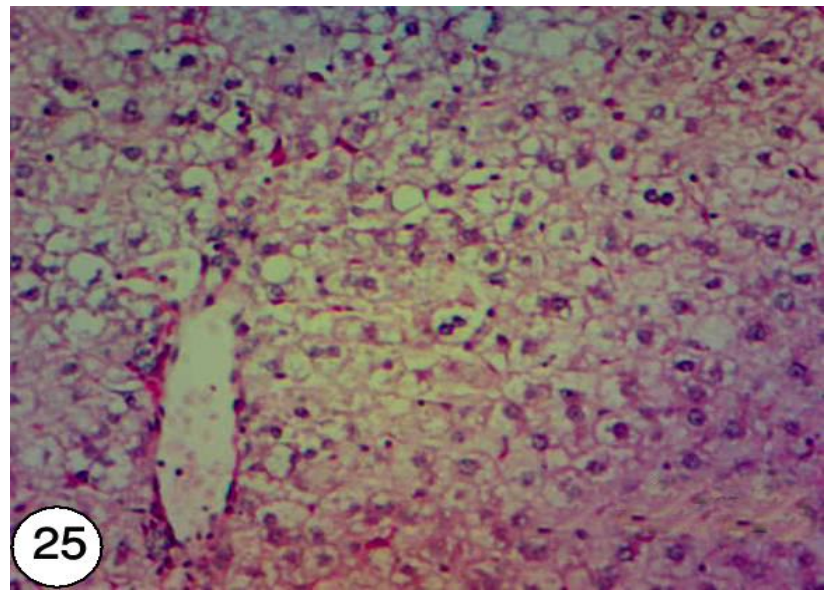

Fig.( 25) showing glycogen distribution in the liver tissue of a rat treated with fats only for 6 weeks .

Notice : Highly depleted hepatocytes in the portal and central areas, endothelia lining of the central vein with increased stain affinity in the thickened arterial wall $(\pi)$.

(PAS X 100).

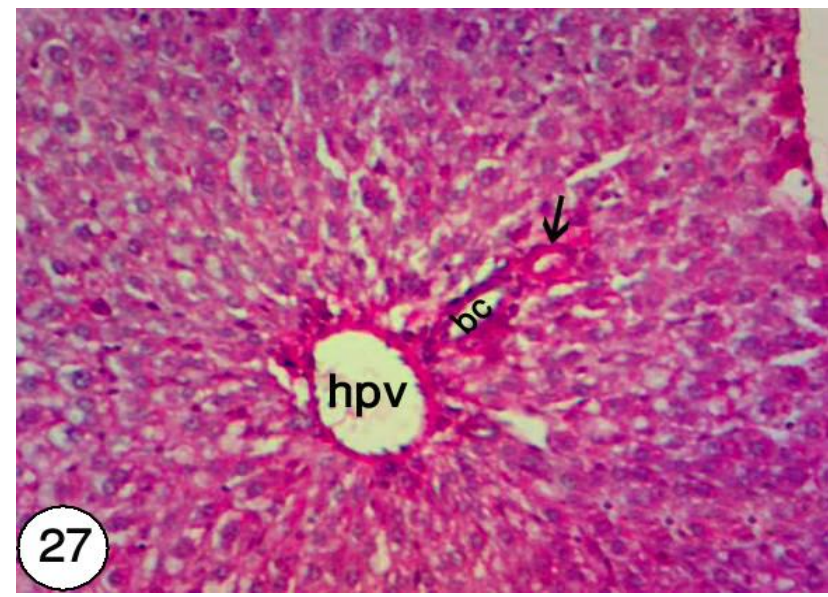

Fig.(27) showing glycogen distribution in the liver tissue of a rat treated with fats for 3 weeks and left 3 weeks for recovery.

Notice: Moderate stain affinity of glycogen in hepatocytes in the portal and central areas with normal stain affinity in the walls of hpv, artery $(\lambda)$ and bile canaliculi (bc).

( PAS X 100).

Figs.(29) showing glycogen distribution in the liver tissue of a rat treated with fats and Avena sativa for 6 weeks simultaneously

Notice: Nearly normal glycogen content in the central and portal areas.

(PASX 100).

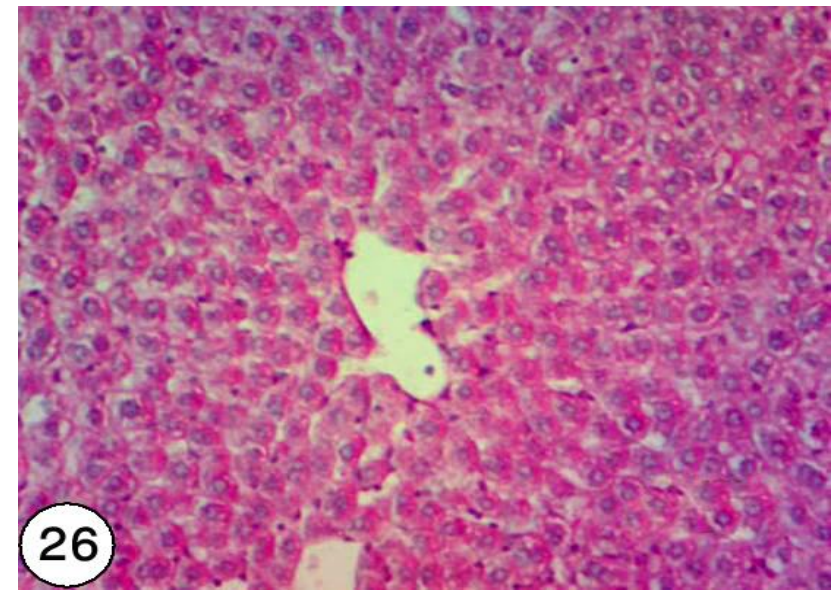

Fig.(26) showing glycogen distribution in the liver tissue of a rat treated with fats for 3 weeks and left 3 weeks for recovery.

Notice: Moderate stain affinity of glycogen in hepatocytes in the portal and central areas with normal stain affinity in the walls of hpv, artery $(\lambda)$ and bile canaliculi (bc).

( PAS X 100).

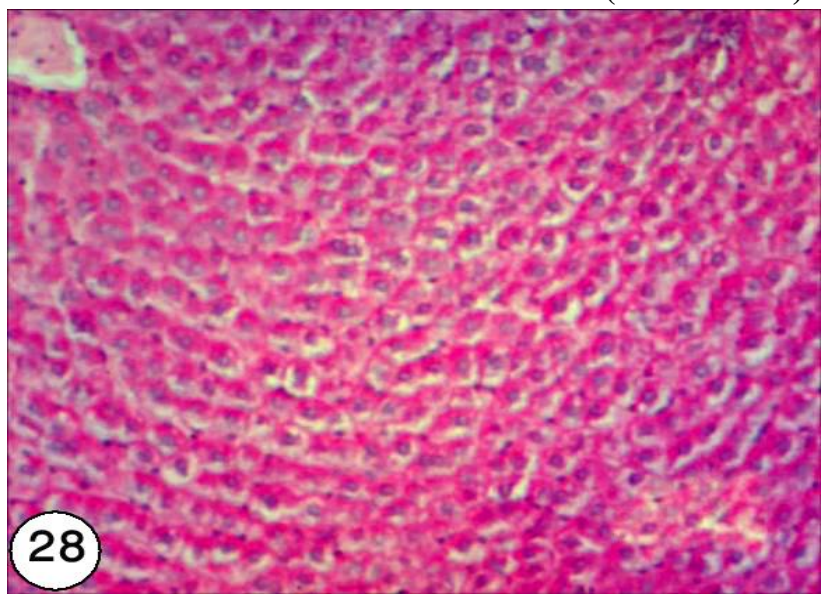

Figs.(28) showing glycogen distribution in the liver tissue of a rat treated with fats and Avena sativa for 6 weeks simultaneously

Notice: Nearly normal glycogen content in the central and portal areas.

(PASX 100).

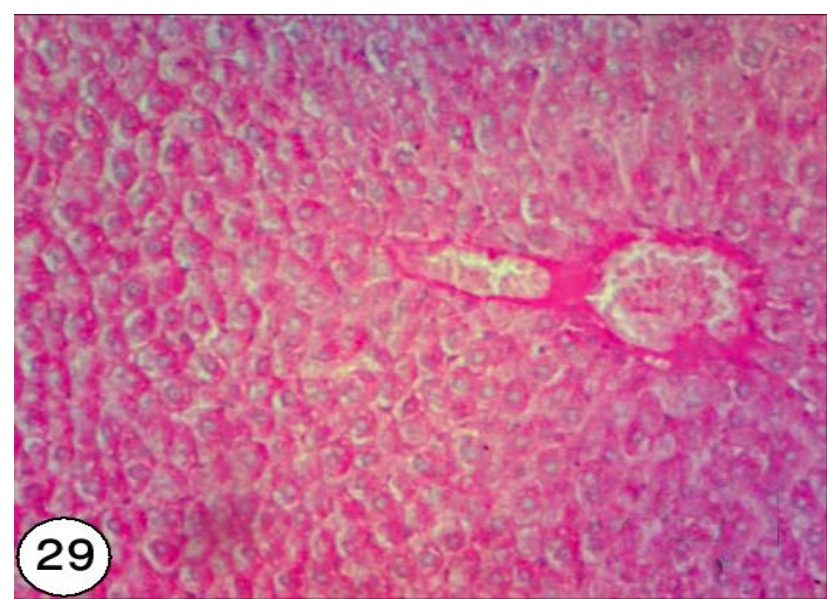




\section{Discussion:}

In recent years, obesity has been considered as one of the main causes of cardiovascular disease, diabetes, and cancer .An increase in the prevalence of obesity and overweight has been widely reported(Brown and Siahpush, 2007).

\section{Body weight:}

In the present study, although all groups recorded highly significant increase $(\mathrm{P}<0.01)$ in the body weight(except the group which treated with oat and has free fat diet)where it showed less body weight gain (it recorded $48.7 \%$ while hyperlipidemic group recorded $134.9 \%$ ), it also was better than recovery group which recorded $97.0 \%$ in comparison with control rats (Table 1$)$.

This may be because its dietary fibers provide less energy as a substitute for nutrients in diets and prolong satiety (Lairon, 2007). In addition, they may slow down the absorption rate of nutrients and bind with dietary fat (Pereira and Ludwig, 2001).

Consequently, the foods rich in dietary fibers may assist body weight control. Also, it was reported that high-fiber and low-fat diet may prevent overweight or obesity and cardiovascular disease in normal adults (Howarth et al., 2005).

Dietary fibers can affect satiety and promote weight loss by several mechanisms such as lowering serum insulin,decreasing food intake since insulin stimulates hunger, slowing gastric emptying, contributing to feeling of fullness and they may increase rates of dietary thermogenesis compared to low-fiber food (Anderson,1990).

\section{Glucose level:}

In the present study using oat with the diet for 3 weeks causes reduction in serum glucose level where it recorded $10.83 \%$, while hyperlipidemic group for 3 weeks recorded $52.7 \%$. Glucose and insulin decreased as the $\beta$-glucan content increased; the highest $\beta$-glucan content resulted in a significant decrease in glucose (Behall et al., 2006). Delayed or reduced carbohydrate absorption from the gut and not the effects of fermentation was suggested as the mechanism of action of oat $\beta$-glucan in postprandial glucose metabolism (Wood et al., 2000).

\section{Liver and heart functions:}

In the present results,rats fed oat (which contains beta-glucan) obviously decreased the levels of ALT and AST in the liver that injured due to feeding high fat diet for 3 weeks. It is concluded that oat $\beta$-glucan can relieve liver injury in hyperlipidemic rats (Suping et al., 2009). Howarth et al. (2005) reported that high-fiber and low-fat diet may prevent cardiovascular disease in normal adults.

\section{Kidney function:}

In the present investigation, highly significant increase $(\mathrm{P}<0.01)$ in serum urea and creatinine was observed in all treated groups. Dyslipidemia is a known risk factor for cardiovascular diseases and may associate with renal injury. In presence of severe hyperlipidemia progressive accumulation of lipids in the kidney drives the cascade of events that leads to impaired organ function (Stevenson and Kaysen, 1999; Majumdar and Wheeler, 2000). Lipid peroxidation, mediated by free oxygen radicals, is believed to be an important cause of destruction and damage to cell membranes, since polyunsaturated fatty acids of the cellular membrane are degraded by this process with consequent disruption of membrane integrity (Garcia et al., 1997). Several mechanisms were proposed for the protective effect of $\beta$-glucan, one of these mechanisms is related to antioxidant capacity of this molecule ( Babincova et al., 2002 and Krizkova et al., 2003). Impairment in renal functions observed in the present study was improved by oat ( $\beta$-glucan) treatment. One of the proposed mechanisms for $\beta$-glucan protection in renal function was free radical scavenging activity (Sener et al., 2006). Membrane peroxidation can lead to changes in membrane fluidity and permeability, and also to enhanced rates of protein degradation, these will eventually lead to cell lysis (Garcia et al., 1997). Sener et al. (2006) reported that 
the antioxidant $\beta$-glucan inhibits elevation of serum urea and creatinine and reverses it back to the control levels. Reiter et al.(2001) proposed that impairment of antioxidant defense mechanisms could permit enhanced free radical induced renal tissue damage. They added that $\beta$-glucan, which is known to have immunomodulatory effects has antioxidant properties.

\section{Protein profile:}

Increased serum total protein and albumin observed in the present study may be due to increased amino acids synthesis. This increase in protein synthesis may be due to the increase in the amount and availability of mRNA

( Peavy et al., 1985), increase in translation factor( Wool et al., 1986) and increase in ribosomal protein synthesis as a result of hyperlipidemia. Adam et al. (2007) suggested that diets high in vegetable protein may permit safe weight loss in overweight or obese patients with chronic kidney disease (CKD). Oat protein is nearly equivalent in quality to soy protein which has been shown by the World Health Organization to be the equal to meat, milk, and egg protein (Anderson et al., 1990). In rats with obesity-related nephropathy, a soy diet, improved renal function, proteinuria, glomerulosclerosis, and interstitial fibrosis (Trujillo et al., 2005).

\section{Lipid profiles:}

The present results showed that oat significantly lowered serum total lipids and recorded highly significant decrease in liver total lipids. This may be due to $\beta$-glucan have a lower molecular weight (BG370) rather than higher molecular weights (BG 1450 and BG 730) which significantly affected the levels of total lipid in serum (Wilson et al., 2004).

Dietary fibers, as oat may affect postprandial lipid metabolism by several mechanisms such as: (1) altering gastric emptying ,(2) influencing intestinal transit time secretion, (3) modifying pancreatic secretion or pancreatic enzyme activity (4) acting on micelle formation (Deshaies $\boldsymbol{e t}$ al.,1990 ).
The present results revealed that oat reduces the cholesterol level in rats that fed a high fat diet, where it recorded $14.1 \%$, while hyperlipidemic group recorded $61.5 \%$, and recovery group recorded $44.1 \%$. These results may be due to oat's fibers operating on cholesterol through completely different mechanisms, such as alter the metabolism of bile acids and sterol faecal excretion, the reduction of nutrient absorption or cholesterol synthesis may be inhibited by short-chain fatty acids produced by fermentation in the colon

( Moundras et al., 1994 ; Olleros et al., 1999).

Beneficial effects of high dietary fiber intake as oat $\beta$-glucan in patients with hyperlipidemia were detected with a significant decrease of triglycerides and LDL-Cholesterol (Chandalia et al., 2000). The present results elucidated that HDLCholesterol concentration showed highly significant decrease $(\mathrm{P}<0.01)$ in all the treated groups, but group that treated with oat and fed free fat diet showed the best results where it recorded $-9.6 \%$, while hyperlipidemic group recorded $-16.3 \%$, also it recorded better result than recovery group which recorded $-14.6 \%$ as compared with the control group.

$\beta$-glucan from oat decreased serum LDL cholesterol and increased bile acid excretion which promotes bile acid synthesis from cholesterol, so it increase LDL cholesterol uptake in the liver(Theuwissen and Mensink,2008). Yu et al.(2002) reported that radical scavenging of oat components could reacts with radicals by donating protons (free radical quenching), radical addition, redox reaction (electron transfer) and radical combination .

The oat which is a species of cereal grain has potent beneficial health effects in reducing LDL-cholesterol and should be included in the prudent diet of individuals with hyperlipidemia (Al-Rawi, 2007).

\section{The histopathological study:}

Rats treated with fats for 3 or 6 weeks showed many pathological changes in the liver tissue. These changes were more pronounced in liver tissue of group H6. 
These changes include: ruptured endothelial lining of the blood vessels, enlarged nuclei of the endothelial lining, increased lymphocytic infiltration in the portal area, haemolysed RBCs inside the blood vessels with degenerated and vacuolated hepatocytes and fatty cells. The hepatic portal areas lost their normal architecture and contained highly distorted blood vessels and bile canaliculi.

Hyperlipidemia is known to enhance the risk of fatty liver disease (Festi et al., 2004) and carcinogenesis which is associated with hydroxyl radical formation (Tseng et al., 1996). Nuclear changes observed in the present study are in accordance with the results of Nayana and Janardhanan (2000) who stated that reactive oxygen species (ROS) such as superoxide anions $\left(\mathrm{O}_{2}\right)$, hydrogen peroxide $\left(\mathrm{H}_{2} \mathrm{O}_{2}\right)$, hydroxyl radical $(\mathrm{OH})$ and nitric oxide $(\mathrm{NO})$ are directly or indirectly involved in DNA damage leading to mutations.Low grade inflammation, endothelial dysfunction and decreased fibrinolysis were associated with increased cardiovascular risk caused by hyperlipidemia (Pidker et al., 2002).

In the present study, rats of group $\mathrm{R}$ showed a slight improvement in the hepatic tissue, but noticeable sings of recovery were detected in liver tissue treated with fats for 3 weeks and then treated with Avena sativa for 3 or 6 weeks. Well developed blood vessels and hepatocytes were detected with the exception of increased lymphocytic infiltration and haemolysed RBCs in the portal area. Hyperlipidemia leads to fatty liver disease which is associated with hydroxyl radical formation, these radicals may be responsible for degenerative changes observed in the liver of hyperlipidemic rats. Several authors showed that oats contained sevnumerous beneficial components such as vitamin $\mathrm{E}$ ( $\alpha$-tocopherol), phenolic acids, flavonoids, sterols and $\beta$-glucan (Nie et al., 2006; Theuwissen and Mensink, 2008).

Several authors mentioned that oats contained $\beta$-glucan which is shown to posses potent antioxidant and free radical scavenging capabilities (Bobeck and
Calbavy, 2001; Kenneth and Hunter, 2004).

Results of the present study showed increased stain affinity of collagen fibers in liver of rats of groups H3, H6 and R, especially around the haepatocytes, walls of hepatic portal veins and the arterial walls with decreased stain affinity in the wall of the central vein.

Horn et al. (1985) declared that the presence of collagen in the presinusoidal spaces might affect the blood supply to liver cells and would reduce the exchange of metabolitesmay cause hepatocellular dysfunction and necrosis.Liver of rats of group $\mathrm{H} 3 A$ \& H6A showed increased collagen fibers in walls of blood vessels, hepatocytes and sinusoidal spaces.

Rousovan et al. (1992) declared that the increase in collagen fibers may be due to increased interstitial tissue and the white fibers under the effect of physical factors, but Hassan et al. (1988) reported that increased collagen fibers may lead to increase the defense reaction against toxic materials.

\section{The histochemical study:}

Highly reduced total protein was detected in liver tissue of groups H3 \& H6, but nearly normal protein content was realized in hepatocytes of liver tissue of group R, but a mild decrease was noted in walls of the blood vessels and bile canaliculi.

Nearly normal protein content was observed in liver tissue of groups $\mathrm{H} 3 \mathrm{~A}$ and H6A. Some vacuolated hepatocytes and fatty cells were negatively stained with deeply stained RBCs inside the congested central vein and the hepatic portal vein.According to El-Banhawy et al. (1986) decreased protein content in the liver tissue may be due to increased action of lytic enzymes.

Highly decreased PAS positive materials were detected in liver tissue of groups $\mathrm{H} 3$ \& H6, but thickened arterial walls were deeply stained.

Most hepatocytes of liver tissue of group R, showed normal content of PAS positive materials.

Signs of improvement in liver tissue of rats treated with fats for 3 or 6 weeks and Avena 
sativa was accompanied by restored glycogen content in the liver tissue.

Highly affected glycogen content observed in this study in liver of rats treated with fats may be due to altered insulin levels and insulin sensitivity or insulin resistance due to obesity. The present results are in parallel with those recorded by Han et al. (2007).

\section{Conclusion \& recommendations:}

Results of the present study showed that oat has hypolipidemic action specially when used with free fat diet for treating hyperlipidemia.So,we recommended to use it in treatement hyperlipidemic patients.

\section{References:}

Adam M, Bernstein M D Leo-Treyzon M D and Zhaoping L I (2007): Are high-protein, vegetable-based diets safe for kidney function? J. Am. Diet Assoc., 107: 644-650.

Al-Rawi M M (2007): Efficacy of oat bran (Avena Sativa) in comparison with atorvastatin in treatment of hypercholesterolemia in albino rat liver. J.Hospt.Med. 29:511-521.

Anderson J W (1990) Dietary fiber and human health.Hort.Sci.25:1488-1495.

Anderson J W,Deakins D A, Floore L, Smith B M and Whitis S E (1990): Dietary fiber and coronary heart disease, Crit. Rev. Food Sci. Nutr., 29: 95 - 147.

Babincova M, Bacova $Z$, Machova $E$ and Kogan G (2002): Antioxidant properties of carboxymethyl glucan: comparative analysis. J. Med Food, 5: 79-83.

Behall M K,Scholfield J D and Hallfrisch G J (2006): Barley B-glucan reduces plasma glucose and insulin responses compared with resistant starch in men.Beltsville Human Nutrition Research Center. Dep.of Agricul.Beltsville, USA. 20705- 2350.

Bell S, Goldman V M, Bistrian B R, Arnold A H, Ostroff G and Forse R A (1999): Effect of $\beta$-glucan from oats and yeast on serum lipids. Crit. Rev. Food Sci. Nutr. , 39: 189-202.

Bergmeyer H U (1978): Principles of enzymatic analysis. Verlag. Chemic, 21 (5): 823-887.

Bobeck $P$ and Calbavy S (2001): Effect of pleuran (beta 1, 3 D-glucan from pleurotus) on the antioxidant status of the organism and dimethyl hydrazine induced precancerous lesions in rat colon. Br. J. Biomed. Sci., 58 (3): 164-168.

Bourdon I,Yokoyama $W$ and Davis $P$ (1999): Postprandial lipid,glucose, insulin and cholecystokinin responses in men fed barley pasta enriched with B- glucan. Am. J. Clin. Nutr., 69: 55-63.

Braaten J T, Wood $P$ J and Scott F W(1994): oat B- glucan reduces blood cholesterol concentration in hypercholesterolemic subjects. Eur. J.Clin. Nutr., 48:465-474.

Breuer J (1996): Report on the symposium "Drug effects in clinical chemistry methods". Eur.J.Clin. Chem. Clin. Biochem., 34:385-386.

Brown A and Siahpush M (2007): Risk factors for overweight and obesity. National Health Survey. Public Health, 121:603-613.

Burstein M (1970): Rapid method for isolation of lipoproteins from human serum by precipitation with poly-anion. J.of lipid Research, 11:583- 588.

Chandalia M,Garg A, Lutijohann D, Bergmann K V,Grundy S M and Brinkley $L$ J (2000): Beneficial effects of high dietary intake in patients with type 2 diabetes mellitus. Eng. J. Med., 342: 1392-1398.

Choudhary M I, Naheed S,Abd El Jalil S, Alam J M and Abd el-Rahman A (2005): Effects of ethanolic extract of Iris germenica on lipid profile of rats fed on a high-fat diet. J. Ethnopharmacol., 98: 217-220.

Davidson H H, Dugan L D, Burns J H, Bava J, Story K and Drennan K B (1991): The hypocholesterolemic effects of B- glucan in oalmeal and oat bran. A dose - Controlled Study. JAMA., 265: 1833- 1839.

Deshaies Y, Begin F and Savoie L (1990): Attenuation of the meal-induced increase in plasma lipids and adipose tissue lipoprotein lipase by guar gum in rats. J. Nutr., 120: 64-70.

Doumas B T, Watson W A and Biggs H G (1971): Albumin standard and the measurement of serum albumin with bromocresol green. Clin. Chem. Acta., 31:87-96.

Drury R and Wallington E (1980): Carleton's Histological Technique, $4^{\text {th }}$ Ed. Oxford. Univ. Press, New York, Toronto.

El Banhawy M, Al-Zahaby $E$ and Shalaby A (1986): Effect of Cyolane intoxification of the protein contents in epithelial cells of Clarias lazera. Egypt. J. Hisot., 9(1): 69-76.

Festi D, Colecchia A, Sacco T, Bondi M, Roda E and Marchesini G (2004): Hepatic steatosis in obese patients: clinical aspects prognostic significance. Obesity Reviews, 5: 2742. 
Fossati $P$ and Prencie L (1982): Serum triglycerides determined colorimeterically with an enzyme that produces hydrogen peroxide. Clin. Chem., 28-2077.

Friedewald W T, Levy R I, Fredrichsor D S (1972): Estimation of the concentration of lowdensity lipioprotein cholesterol in plasma without use of the preparative ultracentrifuge. Clin Chem., 18:499-502.

Garcia J, Reiter R J, Guerrero J M, Escames G, Y B and Oh C S (1997): Melatonin prevents changes in microsomal membrane fluidity during induced lipid peroxidation. FEBS. Lett., 408: 297-300.

Han S H,Quon M J,Kim J A and Koh K K (2007): Adiponectin and cardiovascular disease: response to therapeutic interventions. J. Am. Coll. Cardiol., 49: 531-538.

Harrison D, Kathy K G, Hornig B and Drexler H (2003): Role of oxidative stress in atherosclerosis. Amer. J. of Cardio., 91: 7-11.

Hassan H, Ghaly E, El-Nashar A and Manggoud H (1988): Histochemical study on some organs of rats fed rape seed and cotton seed oils. Egypt. J. Histol., 11(2): 247-252.

Henry R J, Cannon D C and Winkelman J W (1974): Clinical Chemistry Principles and Techniques, Harper and Row. New York, 14401452.

Horn T, Jung J and christoffersen P (1985): Alcoholic liver injury: early changes of the Disse space in acinar zone. Liver, 6: 301-310.

Howarth N C, Hunag TT, Roberts S B and McCrory M A (2005): Dietary fiber and fat are associated with excess weight in young and middle - aged US adults. J. of the American Diet. Associat., 105:1365-1372.

Jaffe M (1980): determination of creatinine in serum. Phys. Chem., 10-391.

Kaplan A (1984): Quantitative Determination of Total Lipids. Clin. Chem. The C.V.Mosby Co. St. Louis. Toronto. Priceton, 919-932.

Kenneth W and Hunter J (2004): Micro particulateß-glucan upregulates the expression of B7.1, B7.2, B7-H1, but not B7-DC on cultured murine peritoneal macrophages. Immunol. Lett., 93 (1): 71-78.

Krizkova L, Durackova Z, Sandula J, Slamenova D, Sasinkova $V$ and Sivonova $M$ (2003): Fungal beta-(1-3)-D-glucan derivatives exhibit high antioxidative and antimutagenic activity in vitro. Anticancer Res., 23: 27512756.

Lairo D (2007): Dietary fiber and control of body weight. Nutr. Metabol.and Cardio. Dis., 17:1-15.
Majumdar A and Wheeler D C (2000): Lipid abnormalities in renal disease. J.R. Soc. Med., 93: 178-182.

Mazia D ,Brewer P and Alfert M (1953): The cytochemical staining and measurement of protein with mercuric bromophenol blue. Biol. Bull., 104: 57-67.

Mensink R P and Katan M B (1992): Effect of dietary fatty acids on serum lipids and lipoproteins: a meta-analysis of 27 trials. Arterioscler Thromb., 12: 911-919.

Moundras G, Bher S R, Demigne, C.; Mazur, A. and Remesy, C. (1994): Fermentable polysaccharides that enhance fecal bile acid excretion lower cholesterol and apolipoprotein E-rich HDL in rats. J. Nutr., 124:2170-2188.

Nayana, J. and Janardhanan, K. K. (2000): Antioxidant and antitumor activity of Pleurotus florida. Curr. Sci., 79: 941-943.

Nicolosi, R.; Bell, S.J.; Bistrian, B.R.; Greenberg, I.; Forse, R.A. and Blackburn, G.L. (1999): Plasma lipid changes after supplementation with B- glucan fiber from yeast. Am. J. Clin. Nutr., 70: 208212.

Nie L, Wise M L, Peterson D M and Meydani M(2006): Avenanthramide, a polyphenol from oats, inhibits Vascular smooth muscle cell proliferation and enhances nitric oxide production. Atherosclerosis, 186: 260266.

Olleros L P, Cuevas M G, Roso B R and Requejo A (1999): Comparative study of natural carbohydrates fibers and psyllium husk in rats. Influence on some aspects of nutritional ultilization and lipidaemia. J. Sci. Food Agric., 173-178.

Patton C J and Crouch S R (1977): A Colorimetric method for the determination of blood urea concentration. J. Anal. Chem., 49:464-469.

Pearse A (1977): Histochemistry, Theoretical and Applied. $3^{\text {th }}$ ed., vol. 1. Churchill Livingstone, London.

Peavy D E, Taylor $J$ M and Jefferson $L ~ S$ (1985): Time course of changes in albumin synthesis and mRNA in hyperlipidemic rats. Am. J. Physiol., 248:656-663.

Pereira M A and Ludwig D S (2001): Dietary fiber and body weight regulation: observations and mechanisms. Pediat. Clin. Of Nor. Ameri., 48: 969-980.

Peterson D (2001): Oat antioxidants. J. Cereal Sci., 33: 115- 129.

Pidker P M, Rifai N,Rose L, Buring J E and Cook N R (2002): Comparison of Creactive protein and low-density lipoprotein 
cholesterol levels in the prediction of first cardiovascular events. N. Engl. J. Med., 347 (20): 1557-1565.

Reihner E, Angelin B, Rudling M, Ewerth S, Bjorkhem I and Einarsson $K$ (1990): Regulation of hepatic cholesterol metabolism in human: Stimulator effects of cholestyramine on HMG - CoA reductase activity and low density lipoprotein receptor expression in gallstone patients. J. Lipid Res., 31: 2219- 2226.

Reiter R J, Tan D X, Manchester L C and Qi $W$ (2001): Biochemical reactivity of melatonin with reactive oxygen and nitrogen species: a review of the evidence. Cell Bioch. Bioph., 34: 237-256.

Rousovan A, Kanje M and Mild K (1992): The stimulatory effect of magnetic field on regeneration of the rat sciatic nerve is frequency dependent. Exp. Neurology, 117: 81-84.

Sener G, Sert G, Sehirli A O, Arbak S, Uslu B, Gedik N and Ananoglu-Dulger G (2006): Pressure Ulcer-induced oxidative organ injury is a meliorated by $\beta$-glucan treatment in rats. Marmara Univers.. Depart. of Pharmac. Istanbul, Turkey, 6: 724 -732.

Snedecor G W and Cochran W G (1980): Statistical Method. State University Press, Lowa, 59-60.USA.

Stevenson F T and Kaysen G A (1999): Hyperlipidemia and renal disease: The use of animal models in understanding pathophysiology and approaches to treatment. Wien Klin Wochenschr, 111: 307-314.

Suping P, Wenjun M, Hao S, Ying W and Li $M$ (2009): The hepatoprotective effect of oat $\beta$ glucans on liver injury in hyperlipidemia rats. Acta Nut. Sinica, Institute of Hygiene and Environmental Medicine, 31 (1): 55-58.

Szasz G and Persijn J P (1974): Determination of g-glutamyl transferase (g-glutamyl) - peptide: amino acid g-glutamyltransferase. Clin. Chem. Biochem., 212-228.

Theuwissen E and Mensink R P (2008): Water - Soluble dietary fibers and cardiovascular disease.Physiol.Behav., 94: 285292.

Tietz N W (1994): Determination of total proteins. Fundamentals of Clinic. Chemis. Saunders Co., London, Philadelphia, 692-772.

Trinder P (1984): Determination of blood glucose Using 4- Aminophenazone. Clin. Path., 222-246.

Trujillo J, Ramirez V and Perez J (2005): Renal protection by a soy diet in abese zucker rats is associated with restoration of nitric oxide generation. Am. J. Physiol. Renal physiol., 288: 108-116.

Tseng T H, Hsu J D, Chu C Y and Wang C J (1996): Promotion of colon carcinogenesis through increasing lipid peroxidation induced in rats by a high cholesterol diet. Cancer Lett. 100: 81-87.

Wilson $\mathbf{T}$ A, Nicolosi $\mathbf{R} \mathbf{J}$, Delaney $\mathbf{B}$, Chadwell K, Moolchandani V and Kotyla T (2004): Reduced and high molecular weight barley beta-glucans decrease plasma total and non-HDL-cholesterol in hypercholesterolemic Syrian golden hamsters. J. of Nutr., 134:26172622.

Wood PK, Beer M U and Butler G (2000): Evaluation of role of concentration and molecular weight of oat B-glucan in determining effect of viscosity on plasma glucose and insulin following an oral glucose load. Brit.J. Nutr., 84: 19-23.

Wool I G, Strire - Walt W S, Karrhara K, Low R B, Bailey P and oyer p (1986): Mode of action of insulin in regulation of protein biosynthesis in muscle. Recent progress in hormone research. New York, Academic Press, Pp: 124-139.

Young D S (1990): Effect of drugs on clinical laboratory tests. AACC. Pres. Washington, D.C., 32:639-655.

Yu L, Haley S, Perret J, Harris $M$ and Wilson $J$ and Quin, $M$ (2002): free radical scavenging properties of wheat extracts. J. Agric. Food chem.., 50: 1619-1624. 


\section{دراسات بيوكيميائية وهستولوجية وكيميانسيجية لنبات الشوفان على الجرذان المصابة بزيادة الدهون إيمان جمال الاين عزت هلال ، فاطمة عيد وأميرة محمد صلاح الدين

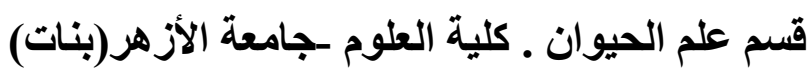

إستهدفت هذه الدراسه إيضاح الدور الوقائى لنبات النشوفان ضد الأخطار الناتجه عن زيادة الدهون على بعض المعايير البيو كيميائية وقسمت هذه الحيو انات إلى المجموعات التاليه: ا ـ المجمو عة الأولى:- استخدمت كمجمو عه ضابطه.

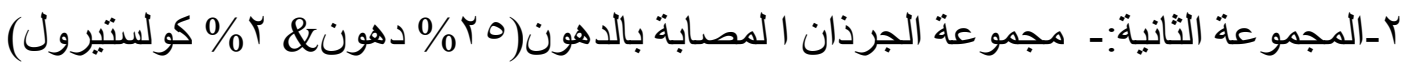
لمدة r أسابيع فقط ثم تم ذبحها.

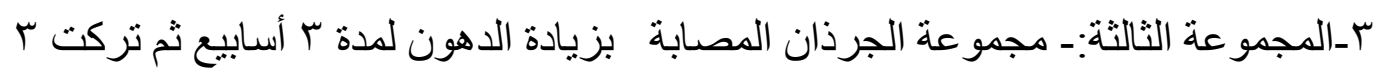
أسابيع بدون أى علاج إضافى كفترة إستثفاء.

ع ـ المجموعة الر ابعة:_الجرذان المصابة بزيادة الدهون باسابيع ثم عولجت بنبات الثوفان الثان

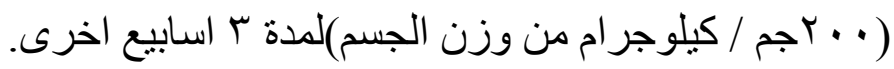

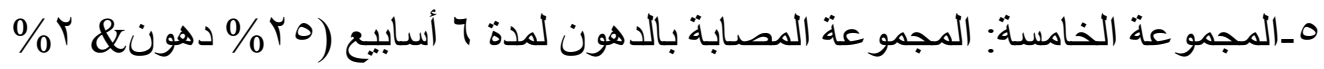

$$
\text { كولستيرول). }
$$

جـ_الهجموعة السادسة:- مجمو عة الجرذان الدصابة بزيادة الدهون وفى نفس الوقت تتاولت

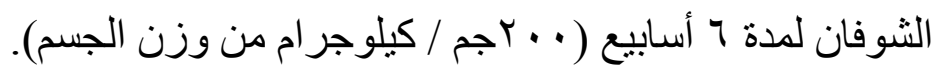

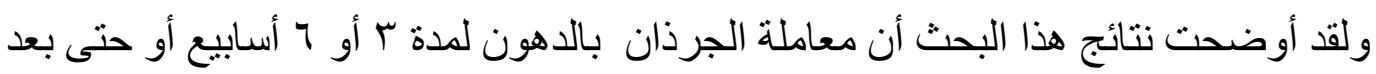

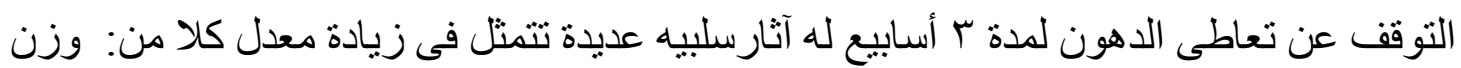
الجسم- نسبة السكر فى الدم-وظائف الكلىـ وظائف الكبد و إنزيمات القلبـ البروتين الكلى.

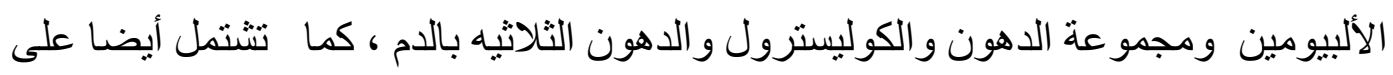
النقص الثديد فى HDL-Cholesterol وصاحب كل ذلك وجود عدد كبير من التغيرات

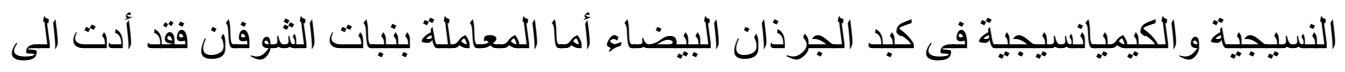
ظهور تحسن ملحوظ فى المعايير البيوكيميائية والهستولوجية والهستوكيميائية ولهذا ينصح بإستخدام

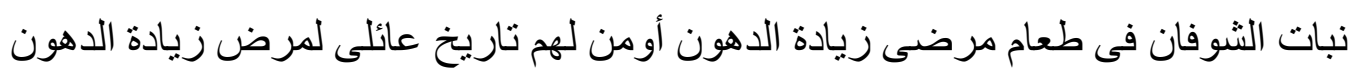

